Check for updates

Cite this: RSC Adv., 2020, 10, 13507

Received 1st February 2020

Accepted 15th March 2020

DOI: $10.1039 /$ d0ra00990c

rsc.li/rsc-advances

\section{Synthesis of $\alpha$-indolylacrylates as potential anticancer agents using a Brønsted acid ionic liquid catalyst and the butyl acetate solvent $\dagger$}

\author{
Ahmed El-Harairy, (iD *ab Mennatallah Shaheen, (DD c Jun Li, ${ }^{\text {b }}$ Yuzhou Wu, (iD b \\ Minghao Li iD ${ }^{b}$ and Yanlong Gu iD bd
}

\begin{abstract}
In this study, new $\alpha$-indolylacrylate derivatives were synthesized by the reaction of 2 -substituted indoles with various pyruvates using a Brønsted acid ionic liquid catalyst in butyl acetate solvent. This is the first report on the application of pyruvate compounds for the synthesis of indolylacrylates. The acrylate derivatives could be obtained in good to excellent yields. A preliminary biological evaluation revealed their promising anticancer activity $\left(\mathrm{IC}_{50}=9.73 \mu \mathrm{M}\right.$ for the compound $\left.4 \mathrm{l}\right)$ and indicated that both the indole core and the acrylate moieties are promising for the development of novel anticancer drugs. The Lipinski's rule and Veber's parameters were assessed for the newly synthesized derivatives.
\end{abstract}

\section{Introduction}

The chemistry of indoles is an extensive research topic in organic synthesis because indole derivatives have unique biological activities. ${ }^{1}$ In the diverse chemical libraries of reported potent antitumor agents, several indole-based derivatives have been described as effective antitumor agents. ${ }^{2}$ Moreover, acrylate-containing derivatives have been proven to display prominent antitumor potency. ${ }^{3}$ Caffeic acid phenethyl ester (CAPE) (Fig. 1) is the main constituent of propolis, a resinous substance used in folk medicine for treating various ailments. CAPE has been widely reported to possess antitumor activities. ${ }^{2 a}$

Herein, our rational design is based on molecular hybridization. Molecular hybridization is a useful approach to design new biologically active agents. It involves the combination of two or more pharmacophoric entities with relevant biological activities to attain new hybrids with improved activity, selectivity, and safety. ${ }^{4}$ In addition, two structural motifs were considered in the design of the proposed scaffold: the indole moiety and the acrylate structure. Although the acrylic linkage has significant potency, a literature survey revealed that only few studies have been reported on the synthesis of $\alpha$ -

${ }^{a}$ Environmental, Energy and Green Chemistry Laboratory, Faculty of Agriculture, Damietta University, 34511, Damietta, Egypt. E-mail: ahmed.elharairy@hotmail.com ${ }^{b}$ School of Chemistry and Chemical Engineering, Huazhong University of Science and Technology, 430074, Wuhan, China

'Department of Pharmaceutical Chemistry, Faculty of Pharmacy, Horus University, 34511, New Damietta, Damietta, Egypt

${ }^{d}$ State Key Laboratory for Oxo Synthesis and Selective Oxidation, Lanzhou Institute of Chemical Physics, Lanzhou, 730000, China

$\dagger$ Electronic supplementary information (ESI) available. CCDC 1980793. For ESI and crystallographic data in CIF or other electronic format see DOI: 10.1039/d0ra00990c indolylacrylate analogs ${ }^{5}$ and their biological activity as promising anticancer agents was evaluated in 2020 for the first time (Fig. 2). ${ }^{6}$

Some methods, such as a straightforward strategy involving the use of a Michael acceptor for the synthesis of $\alpha, \beta$-unsubstituted indoles, have been developed to transform $\mathrm{C}-\mathrm{H}$ bonds into $\mathrm{C}-\mathrm{C}$ bonds by Friedel-Crafts alkylation and acylation reactions, ${ }^{7}$ also called cross-dehydrogenative coupling (CDC) reactions. $^{8}$

Most of the widely used methods involve the conjugate addition of heterocycles to $\alpha, \beta$-unsaturated carbonyl compounds; however, most of these methods require different catalysts such as chiral transition-metal catalysts and organocatalysts. ${ }^{9}$ Moreover, in another reported study, directing

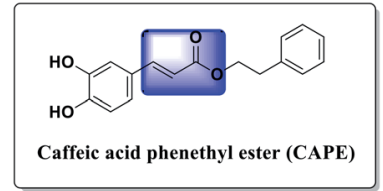

Fig. 1 Chemical structure of caffeic acid phenethyl ester (CAPE).

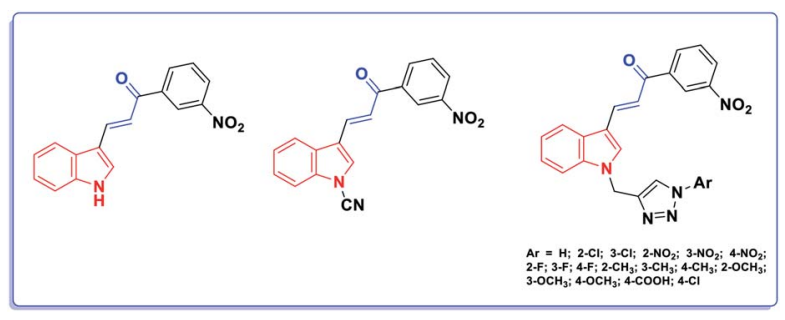

Fig. 2 The reported indole acrylate-based anticancer agents. 


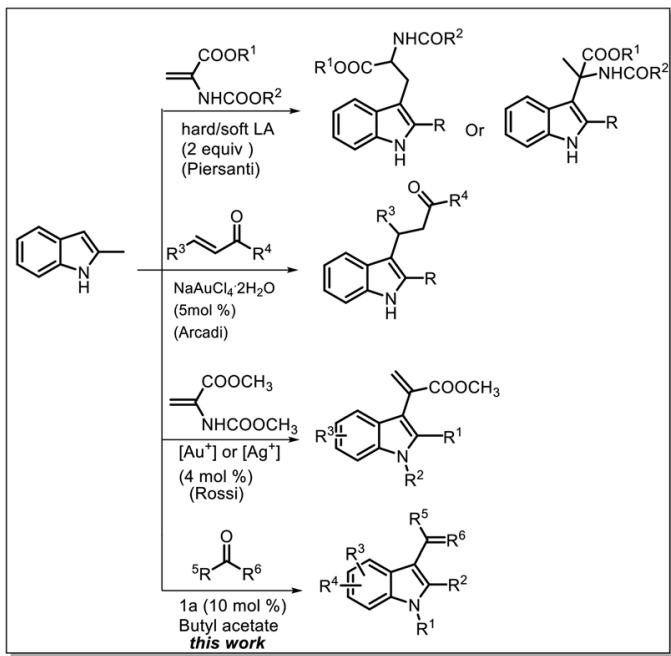

Scheme 1 Routes for the synthesis of C3-functionalized indoles.

groups or auxiliary amine catalysts were used to convert the $\beta$ position to the $\alpha$-position through dehydrogenation at the $\beta$ position; however, studies based on this strategy are rare. ${ }^{10}$ Recently, some studies have reported the use of acrylate derivatives for the synthesis of indolylacrylates under harsh conditions such as the use of expensive catalysts, toxic solvents, and high temperatures (Scheme 1). ${ }^{11}$ Recently, we proposed the use of a sulfone-containing imidazolium-based Brønsted acid ionic liquid as a catalyst and butyl acetate as a solvent to replace dipolar and aprotic solvents. ${ }^{12}$ In this study, we investigated the possibility of using reactive carbonyl compounds, i.e. pyruvates, for the synthesis of $\alpha$-indolylacrylate derivatives under green conditions, and to our delight, highest reactivity of pyruvate with indole was observed in a biphasic system with an ionic liquid as a catalyst and butyl acetate as a solvent.

\section{Results and discussion}

We used our system 1a/butyl acetate ${ }^{12}$ in a simple protocol involving the reaction of 2-methyl indole with ethyl pyruvate as a model reaction (Table 1); this is the first report on the application of pyruvate compounds for the synthesis of $\alpha$-indolylacrylate derivatives and replacement of dipolar, aprotic, and hazardous solvents by butyl acetate.

The reaction of 2-methylindole 2a with ethyl pyruvate $3 \mathbf{a}$ was conducted in a biphasic system at $80{ }^{\circ} \mathrm{C}$ for 30 minutes in the presence of $10 \mathrm{~mol} \%$ of ionic liquid $1 \mathrm{a}$ as a catalyst and butyl acetate as a solvent; the ratio of $\mathbf{2 a / 3 a}$ was $1: 1$, and the product 4a was obtained in an excellent yield (91\%) (Table 1, entry 1). With the Forbes's ionic liquid $\mathbf{1 b},{ }^{12} \mathbf{4 a}$ was obtained in a $25 \%$ yield (entry 2), whereas with the ionic liquid $1 \mathbf{c},{ }^{12}$ the yield of $\mathbf{4 a}$ was increased to $65 \%$ (entry 3 ). Note that when we replaced the butyl acetate solvent with the ethyl acetate solvent, the yield of 4a reached $70 \%$ (entry 4). Strong acids, such as triflic acid and PTSA, were used with the butyl acetate solvent, and $4 \mathbf{a}$ was obtained in $50 \%$ and $47 \%$ yields (entries 5 and 6), respectively. We examined other green solvents such as ethanol and anisole, and 4a could be isolated in $35 \%$ and $40 \%$ yields, respectively. Nitromethane was tested as a polar solvent, and 4a was obtained in a $10 \%$ yield; moreover, when other dipolar and aprotic solvents, such as 1,2-dichloroethane (DCE) and 1,4-dioxane, were used, the yields of $4 \mathbf{a}$ were $30 \%$ and $7 \%$ (entries 10 and 11 ), respectively. These results indicate that the abovementioned reaction does not require dipolar and aprotic solvents, and the product 4a can be obtained in an excellent yield using weakly-tomoderately polar butyl acetate. Moreover, we investigated the reactivity of the substrate using non-polar solvents such as toluene and benzene, and the yields of $\mathbf{4 a}$ were significantly increased to 70 and $65 \%$ (entry 12 and 13), respectively. In addition, we increased the amount of the ionic liquid catalyst 1a; however, no further increase in the yield was observed (entry 14). On the other hand, when we decreased the amount of the ionic liquid catalyst 1a to $5 \mathrm{~mol} \%$, 4a was obtained in a $72 \%$ yield (entry 15). Moreover, the results of this reaction completely confirmed that a balance between butyl acetate as a solvent and ionic liquid 1a as a catalyst was required and the substrates were more active in this biphasic system. Moreover, the recyclability of the ionic liquid 1a was studied for conducting this model reaction on a large scale using $10 \mathrm{mmol}$ of the substrate to obtain the target product $\mathbf{4 a}$ in a $91 \%$ yield; the results indicated that 1a could be recycled 8 times without any significant loss in its activity, and the recovery of the butyl acetate solvent reached about $96 \%$.

Table 1 The reaction of $2 a$ with $3 a$ under different conditions

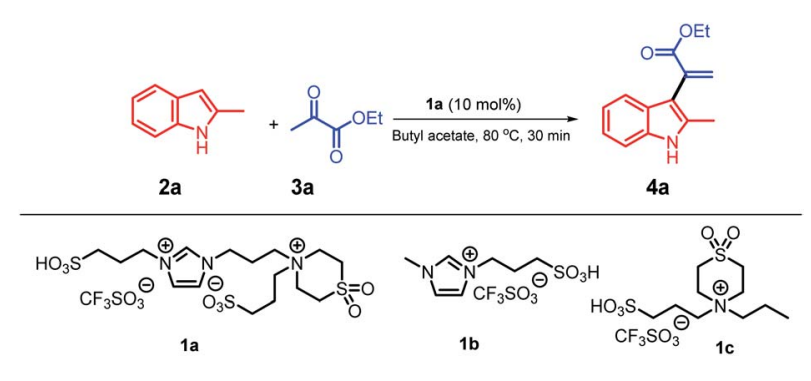

\begin{tabular}{llll}
\hline Entry & Catalyst & Solvent & Yield (\%) \\
\hline $1^{a}$ & 1a & Butyl acetate & 91 \\
2 & 1b & Butyl acetate & 25 \\
3 & 1c & Butyl acetate & 65 \\
4 & 1a & Ethyl acetate & 70 \\
5 & TfOH & Butyl acetate & 50 \\
6 & PTSA & Butyl acetate & 47 \\
7 & TfOH & EtOH & 35 \\
8 & TfOH & Anisole & 40 \\
9 & TfOH & Nitromethane & 10 \\
10 & TfOH & 1,2-Dichloroethane & 30 \\
11 & TfOH & 1,4-Dioxane & 7 \\
12 & TfOH & Toluene & 70 \\
13 & TfOH & Benzene & 65 \\
$14^{b}$ & 1a $(15 \%)$ & Butyl acetate & 91 \\
$15^{c}$ & 1a $(5 \%)$ & Butyl acetate & 72
\end{tabular}

${ }^{a}$ Reaction conditions: $2 \mathrm{a}, 0.3 \mathrm{mmol}$; 3a, $0.3 \mathrm{mmol}$; 4a, $0.3 \mathrm{mmol}$; catalyst, $0.03 \mathrm{mmol}$; medium, $0.5 \mathrm{ml}$; temperature, $80{ }^{\circ} \mathrm{C}$; and time, $2 \mathrm{~h} .{ }^{b}$ Temperature, $60{ }^{\circ} \mathrm{C} .{ }^{c}$ Time, $1 \mathrm{~h}$. 


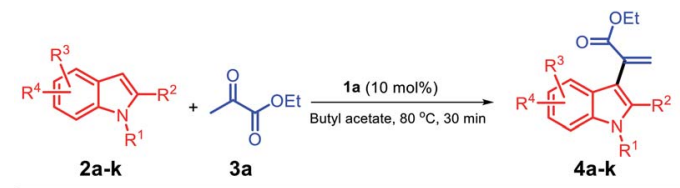

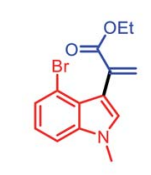

4b $90 \%$

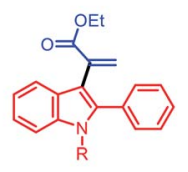

4e R= H $88 \%$

4f $\mathrm{R}=\mathrm{Me} 91 \%$ 4g R= Et $90 \%$
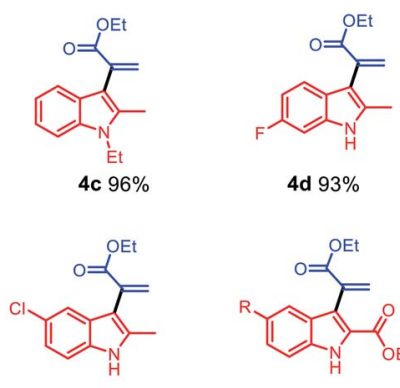

4h $92 \%$

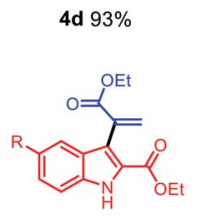

4i R= H 93\% 4j R= OMe $80 \%$ $4 \mathbf{k} R=F 70 \%$
Scheme 2 Scope of the substrates with respect to the indole component.

Based on these results, we selected the condition stated in entry 1 as an identical condition to extend the scope of the substrate by smoothly reacting different varieties of indole substituents with ethyl pyruvate 3a (Scheme 2); moreover, different positions of indole $\mathbf{2 a}-\mathbf{k}$ were investigated for this reaction, and the corresponding $\alpha$-indolylacrylates $\mathbf{4 a}-\mathbf{k}$ with generally excellent to good yields were obtained. Both electronrich (2a, 2c, and $2 \mathbf{e}-\mathbf{g})$ and moderately electron-poor $(\mathbf{2 b}, \mathbf{2 d}$, and $\mathbf{2 h}$ ) indoles readily participated in the reaction; however, when different positions of electron-poor indoles were used, the yield of $4 \mathbf{k}$ was affected and reached $70 \%$. Moreover, when we changed the group at the C5 position to hydrogen and methoxy, $4 \mathbf{i}$ and $4 \mathbf{j}$ were obtained with increased yields, respectively. When electron-rich indoles were used, $\mathbf{4} \mathbf{c}$ and $\mathbf{4 i}$ were obtained in excellent yields (96\% and 93\%), respectively; using indoles with a phenyl group at the $\mathrm{C} 2$ position and different groups at

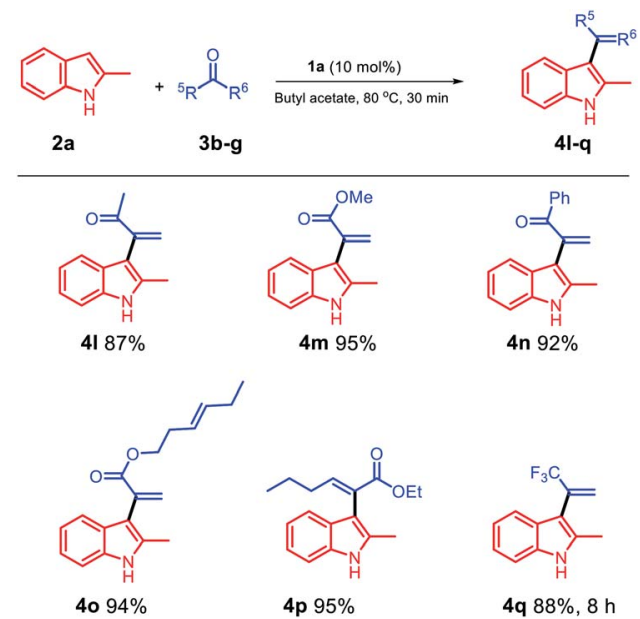

Scheme 3 Scope of the substrates with respect to the ketone component.

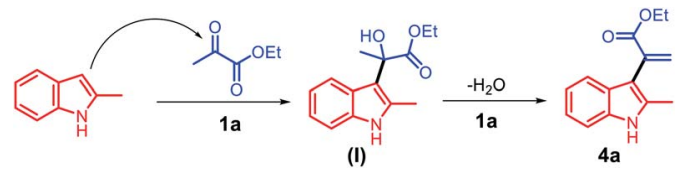

Scheme 4 The proposed reaction mechanism for the synthesis of $\alpha$ indolylacrylates.

the $\mathrm{C} 1$ position, the corresponding products $4 \mathbf{e}, \mathbf{4 f}$, and $\mathbf{4 g}$ could be obtained in $88 \%, 91 \%$, and $90 \%$ yields, respectively. When the moderately electron-poor indoles $2 \mathbf{b}, \mathbf{2 d}$, and $2 \mathbf{h}$ with different groups were used, the corresponding products $\mathbf{4 b}, \mathbf{4 d}$, and $4 \mathrm{~h}$ were obtained in very satisfactory yields ( $90 \%, 93 \%$, and $92 \%$ ), respectively, and no detectable formation of decomposition products occurred.

Then, we probed the scope of the reaction with respect to the ketone component. The reaction of methyl pyruvate with methoxy pyruvate was also investigated, and the products $\mathbf{4 l}$ and $\mathbf{4 m}$ were obtained in excellent yields (Scheme 3). Moreover, we used a pyruvate substrate with a phenyl group at the C5 position, and the obtained product $4 \mathrm{n}$ was isolated with a $92 \%$ yield. In addition, trans-3-hexenyl pyruvate (3e) smoothly reacted with 2-methylindole using butyl acetate as a solvent and 1a as a catalyst, and the trans- $\mathrm{C}=\mathrm{C}$ bond was effectively retained in the product 40 isolated with an excellent yield of $94 \%$. Ethyl 2oxohexanoate was examined in the biphasic system of 1a/butyl acetate, and $\mathbf{4 p}$ was obtained in a $95 \%$ yield. We used trifluoroacetone to see if it would react in the $\mathbf{1 a}$ /butyl acetate biphasic system, and to our delight, the target product $\mathbf{4 q}$ was obtained in an $88 \%$ yield after $8 \mathrm{~h}$.

Based on the abovementioned results, a plausible mechanism was proposed (Scheme 4). The C3 position of 2-methyl indole is a reactive nucleophilic site and can attack the ketone carbonyl group of ethyl pyruvate. The initial episode of the reaction involved the formation of an intermediate hydroxyl group (I) from 2a and 3a in the presence of the acid catalyst 1a. The intermediate (I) can be possibly converted to $4 \mathbf{a}$ by eliminating one molecule of water.
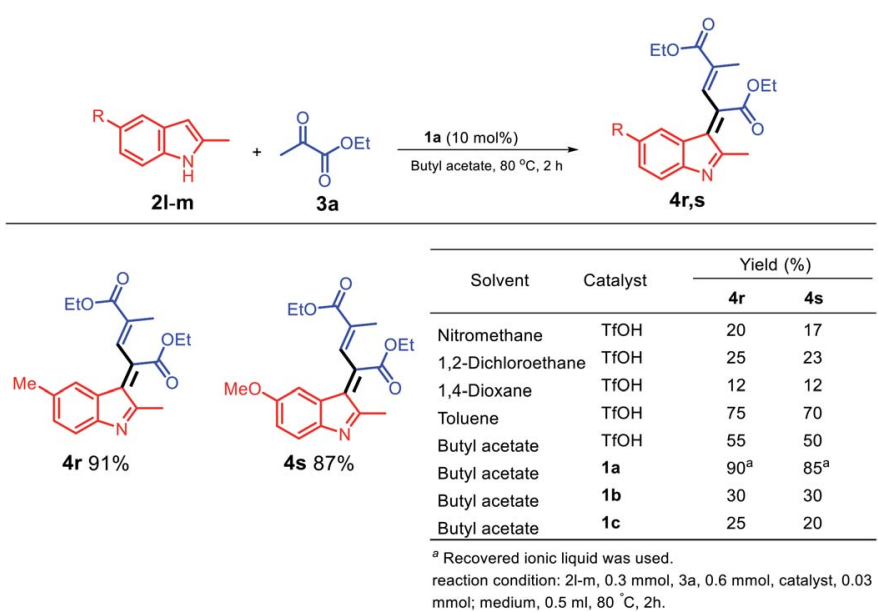

Scheme 5 Schematic for the synthesis of electro-rich indolylacrylates. 
When an electro-rich group, such as methyl and methoxy group, was used at the $\mathrm{C} 3$ position, different structures were obtained; moreover, two molecules of ethyl pyruvate were reacted with one molecule of a 2-methylindole derivative (Scheme 5) to optimize the conditions for the solvents and acid catalysis, and the final products $\mathbf{4 r}$ and $\mathbf{4 s}$ were obtained in excellent yields. However, when a dipolar solvent was used (Scheme 5), $\mathbf{4 r}$ and $4 \mathbf{s}$ were obtained in poor yields; moreover, using the non-polar solvent toluene, the yield of $\mathbf{4 s}$ was increased to $70 \%$. As observed from the table shown in Scheme 5 , the $1 \mathrm{a} /$ butyl acetate system is a unique system because it not only can replace the dipolar aprotic solvent but can also replace a non-polar toxic solvent such as toluene.

Considering the formation of the two products $4 \mathbf{r}$ and $4 \mathbf{s}$, the nucleophilicities of $\mathbf{2 l}$ and $\mathbf{2} \mathbf{m}$ in the presence of acid can be considered as the key for rendering the reaction possible. The C3 positions of $\mathbf{2 l}$ and $\mathbf{2 m}$ are reactive nucleophilic sites that can attack the electrophilic carbonyl group of $\mathbf{3 a}$; using the acid ionic liquid catalyst 1a, the intermediate (I) can be converted to intermediate (II), which has a nucleophilic carbon and can attack the carbonyl group of another molecule of 3a and form the intermediate (III). The abstraction of the $\mathrm{NH}$ proton by the negatively charged oxygen using the Brønsted acid ionic liquid catalyst 1a leads to the formation of (IV), which undergoes water elimination to finally afford the products $4 \mathbf{r}$ and $4 \mathbf{s}$ (Scheme 6).

We studied the reaction of 2-unsubstituted indole with ethyl pyruvate, and the $\mathrm{C} 3$ position of the indole nucleus reacted with the $\alpha$-carbon of ethyl pyruvate to form a new carbon-carbon bond. We optimized the conditions of this reaction using different solvents and catalysts; the ionic liquid was immiscible with the organic phase, thus forming a biphasic reaction system. The designed structure of the ionic liquid 1a involved a cyclic sulfone fragment, which enabled the ionic phase to provide a suitable reaction microenvironment for the stabilization of the reaction intermediate. Other ionic liquids, such as $\mathbf{1 b}$ and $\mathbf{1 c}$, do not have this property due to the lack of a strongly polar part. Moreover, the biphasic system of $\mathbf{1 a}$ /butyl acetate is the best condition for this reaction (Table 2, entry 8).

The unique acidic environment offered by the ionic liquid catalyst 1a should be the key to initiate the dimerization of two molecules of intermediate (I) to form the diester indole intermediate (II); the $\mathrm{C} 2$ position of the indole ring will act as
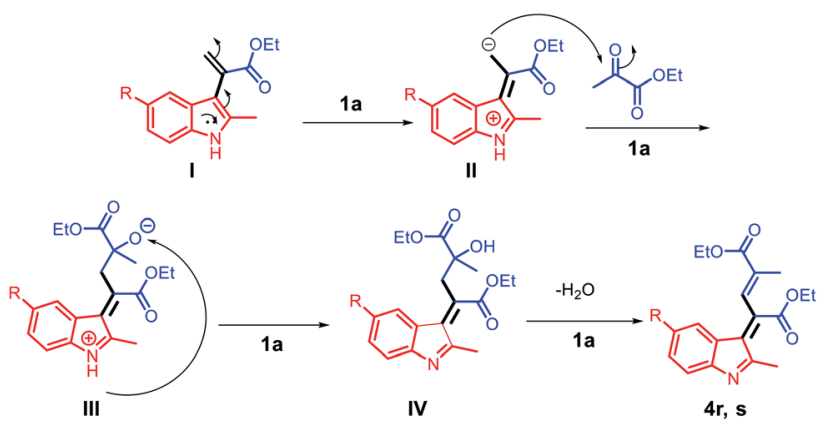

Scheme 6 The proposed reaction mechanism for the synthesis of the compounds $4 \mathrm{r}$ and $4 \mathrm{~s}$.
Table 2 The behaviour of 2-unsubstituted indoles ${ }^{a}$

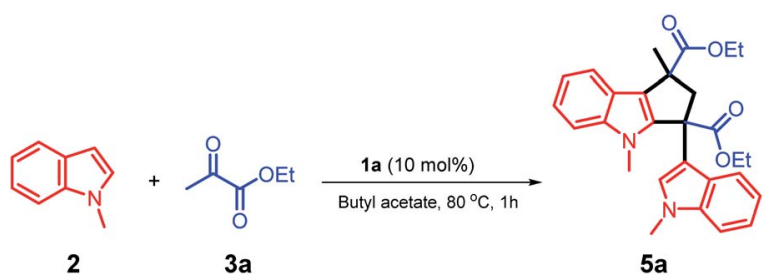

\begin{tabular}{llll}
\hline Entry & Catalyst & Solvent & Yield \\
\hline 1 & TfOH & 1,4-Dioxane & 10 \\
2 & TfOH & 1,2-Dichloroethane & 42 \\
3 & TfOH & MeNO $_{2}$ & 20 \\
4 & TfOH & EtOH & 38 \\
5 & TfOH & Anisole & 15 \\
6 & TfOH & Ethyl acetate & 35 \\
7 & TfOH & Butyl acetate & 42 \\
8 & 1a & Butyl acetate & 92 \\
9 & 1b & Butyl acetate & 33 \\
10 & 1c & Butyl acetate & 63
\end{tabular}

${ }^{a}$ 2a, $0.3 \mathrm{mmol}$; 3a, $0.3 \mathrm{mmol}$, TfOH, $0.03 \mathrm{mmol}$; 1a, $0.03 \mathrm{mmol}$; solvent, $10 \mathrm{ml}, 80^{\circ} \mathrm{C}, 1 \mathrm{~h}$.

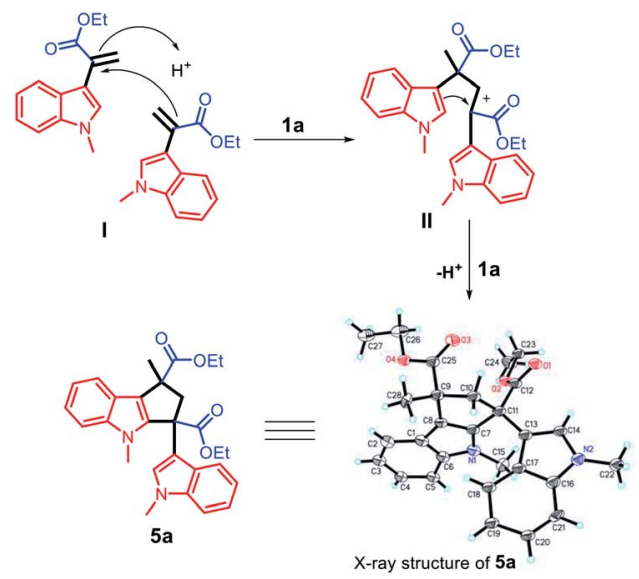

Scheme 7 The proposed reaction mechanism for the synthesis of compound 5 a

a nucleophilic site to attack the positively charged carbon of (II) to afford the product 5a (Scheme 7). The crystal and molecular structures of $5 \mathbf{a}$ were further confirmed using single-crystal Xray diffraction (ESI $\dagger$ ).

Since many organic acrylates and indole-containing compounds have anticancer properties, the newly synthesized $\alpha$-indolylacrylates $\mathbf{4 a}-\mathbf{s}$ and $5 \mathbf{a}$ were screened for their in vitro growth inhibitory potential against the human cervical adenocarcinoma (HeLa) cell line using the 3-(4,5-dimethyldiazol-2-yl)2,5-diphenyltetrazolium bromide (MTT) assay. The MTT cell proliferation assay has been widely accepted as a reliable way to measure the cell proliferation rate when metabolic events lead to apoptosis or necrosis. After incubation with the abovementioned compounds at different concentrations for $24 \mathrm{~h}$, the 


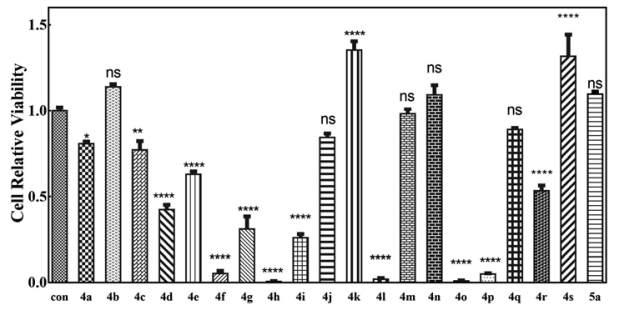

Fig. 3 MTT assays of cell relative viability. (a) Herein, $100 \mu \mathrm{M} 4 \mathrm{a}-\mathrm{s}$ and 5 a were incubated with the HeLa cells for $48 \mathrm{~h}$. ${ }^{\text {ns }}$ represents $P>0.05$, * represents $p$ value $<0.05$, ** represents $p$ value $<0.01$, and $* * * *$ represents $p$ value $<0.001$. The significant difference was compared with the control group.
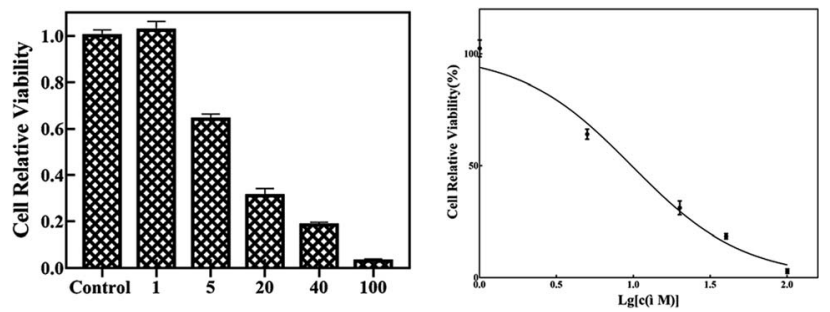

Fig. 4 The compound $4 \mathrm{l}$ at different concentrations was incubated with the HeLa cells for $48 \mathrm{~h}$. The $\mathrm{IC}_{50}$ is $9.73 \mu \mathrm{M}$.

cells were treated with MTT to measure their growth/viability using a spectrophotometer. ${ }^{13}$ The results showed that the synthesized compounds $\mathbf{4 f}, \mathbf{4 h}, \mathbf{4 l}, \mathbf{4 o}$, and $\mathbf{4 p}$ have maximum percentage cytotoxicity at $100 \mu \mathrm{g} \mathrm{m} \mathrm{m}^{-1}$ (Fig. 3). These five compounds were subjected to further cytotoxicity studies against the HeLa cell line to determine the $\mathrm{IC}_{50}$ values. Among these derivatives, the compound $\mathbf{4 I}$ exhibited a potent anticancer activity with the $\mathrm{IC}_{50}$ value of $9.73 \mu \mathrm{g}$ (Fig. 4). In future, several derivatives of $\mathbf{4 l}$ analogs will be subjected to further tests for cytotoxic activity against multiple human cancer cell lines and inhibitory activity against several enzymes to study a comprehensive SAR.

\section{In silico studies}

Molinspiration calculations. The Lipinski's rule of five is a rule of thumb that is used to determine the drug likeness or investigate the properties that would make a chemical compound with a certain pharmacological or biological activity a likely orally active drug in humans. ${ }^{14}$ Similarly, the topological polar surface area (TPSA) and number of rotatable bonds (Nrotb) affect the extent of drug absorption. ${ }^{15}$ Molinspiration software ${ }^{16}$ is an important computational tool for the analysis of the Lipinski's rule parameters TPSA and Nrotb of new compounds. The results (Table 3) illustrated that all the investigated compounds are in agreement with the adequate criteria, i.e. adequate TPSA and Nrotb with zero violation of the Lipinski's rule (except for $\mathbf{5 a}$ with one violation), of Lipinski's rule, and these compounds are predicted to be well absorbed orally in humans.
Table 3 TPSA, Nrotb, and the calculated Lipinski's rule for the new compounds

\begin{tabular}{|c|c|c|c|c|c|c|c|}
\hline \multirow{2}{*}{$\begin{array}{l}\text { Comp. } \\
\text { no. }\end{array}$} & \multicolumn{7}{|c|}{ Molecular properties } \\
\hline & TPSA $^{a}$ & $\operatorname{Nrotb}^{b}$ & $\operatorname{mi} \log P^{c}$ & $n \mathrm{OH}-\mathrm{NH}^{d}$ & $n \mathrm{O}-\mathrm{N}^{e}$ & M. $\mathrm{wt}^{f}$ & $\mathrm{nVs}^{g}$ \\
\hline $4 a$ & 42.10 & 4 & 2.90 & 1 & 3 & 229.28 & 0 \\
\hline $4 b$ & 31.24 & 4 & 3.51 & 0 & 3 & 308.18 & 0 \\
\hline $4 c$ & 31.24 & 5 & 3.35 & 0 & 3 & 257.33 & 0 \\
\hline $4 d$ & 42.10 & 4 & 3.04 & 1 & 3 & 247.27 & 0 \\
\hline $4 e$ & 42.10 & 5 & 4.36 & 1 & 3 & 291.35 & 0 \\
\hline 4f & 31.24 & 5 & 4.42 & 0 & 3 & 305.38 & 0 \\
\hline $4 \mathrm{~g}$ & 31.24 & 6 & 4.80 & 0 & 3 & 319.40 & 0 \\
\hline $4 h$ & 42.10 & 4 & 3.56 & 1 & 3 & 263.72 & 0 \\
\hline $4 i$ & 68.40 & 7 & 3.13 & 1 & 5 & 287.31 & 0 \\
\hline $4 \mathbf{j}$ & 77.64 & 8 & 3.16 & 1 & 6 & 317.34 & 0 \\
\hline $4 \mathbf{k}$ & 68.40 & 7 & 2.30 & 1 & 5 & 305.31 & 0 \\
\hline 41 & 32.86 & 2 & 2.21 & 1 & 2 & 199.25 & 0 \\
\hline $4 \mathrm{~m}$ & 42.10 & 3 & 2.53 & 1 & 3 & 215.25 & 0 \\
\hline $4 n$ & 32.86 & 3 & 3.81 & 1 & 2 & 261.32 & 0 \\
\hline 40 & 42.10 & 7 & 4.20 & 1 & 3 & 283.37 & 0 \\
\hline $4 p$ & 42.10 & 6 & 4.45 & 1 & 3 & 271.36 & 0 \\
\hline $4 q$ & 15.79 & 2 & 3.59 & 1 & 1 & 225.21 & 0 \\
\hline $4 r$ & 65.50 & 7 & 4.35 & 0 & 5 & 341.41 & 0 \\
\hline $4 s$ & 74.74 & 8 & 3.96 & 0 & 6 & 357.41 & 0 \\
\hline $5 a$ & 62.48 & 7 & 5.45 & 0 & 6 & 458.56 & 1 \\
\hline
\end{tabular}

${ }^{a}$ Topological polar surface area. ${ }^{b}$ Number of rotatable bonds. ${ }^{c}$ The parameter of lipophilicity. ${ }^{d}$ Number of hydrogen bond donor sites. ${ }^{e}$ Number of hydrogen bond acceptor sites. ${ }^{f}$ Molecular weight.

${ }^{g}$ Number of violations from the Lipinski's rule of five.

\section{Conclusions}

Herein, using an ionic liquid as a catalyst and butyl acetate as a solvent, we successfully synthesized various $\alpha$-indolylacrylate derivatives via the dehydrative alkenylation of indole derivatives with inexpensive, convenient, and simple ketones. Compared with the established method for the synthesis of $\alpha$-indolylacrylates, the method proposed herein is a green approach involving a cost-effective reaction, high synthetic efficiency, recyclable catalyst, recyclable solvent, and easy product isolation. The newly synthesized compounds were evaluated for their in vitro anticancer activity against a human cervical adenocarcinoma (HeLa) cell line, and the results revealed that the compound 41 was the most active member with the $\mathrm{IC}_{50}$ value of $9.73 \mu \mathrm{M}$. Moreover, based on the results of the Molinspiration calculations, the compound $\mathbf{4 l}$ was predicted to have good oral absorption. Based on the abovementioned results, $4 \mathbf{l}$ is considered to be a promising lead for the future development of new potent antitumor agents.

\section{Experimental}

\section{General remarks}

1-(3-Aminopropyl)imidazole, divinyl sulfone, 1,3-propane sulfonate, trifluoromethanesulfonic acid, $n$-butylamine, 1methylimidazole, 2-methyl-1H-indole, 1-methyl-1H-indole, 2phenyl-1 $H$-indole, 1-methyl-2-phenyl-1 $H$-indole, 1-ethyl-2phenyl-1 $H$-indole, 4-bromo-1-methyl-1 $H$-indole, ethyl 1-methyl- 
$1 H$-indole-2-carboxylate, 1 -ethyl-2-methyl- $1 H$-indole, 6-fluoro-2methyl-1 $H$-indole, 5-methoxy-2-methyl- $1 H$-indole, 2,5-dimethyl$1 H$-indole, ethyl 5-fluoro- $1 H$-indole-2-carboxylate, ethyl 5methoxy- $1 H$-indole-2-carboxylate, and 5-chloro-2-methyl-1 $H$ indole were purchased from Energy Chemical Company. Ethyl pyruvate, biacetyl, 1-phenylpropane-1,2-dione, methyl pyruvate, ethyl 2-oxohexanoate, (E)-hex-3-en-1-yl 2-oxopropanoate, and 1,1,1-trifluoropropan-2-one were purchased from Alfa Aesar Chemical Company. Butyl acetate, ethyl acetate, petroleum ether, sodium chloride, methanol, acetonitrile, acetone, 1,2dichloroethane, anisole, 1,4-dioxane, and ethanol were purchased from Sinopharm Chemical Reagents Limited Company (SCRC). The ${ }^{1} \mathrm{H},{ }^{13} \mathrm{C}$, and ${ }^{19} \mathrm{~F}$ NMR spectra were obtained using Bruker AV-400 (400 MHz ${ }^{1} \mathrm{H}, 100 \mathrm{MHz}^{13} \mathrm{C}$, and 375 $\mathrm{MHz}{ }^{19} \mathrm{~F}$ ) at room temperature. Fourier transform infrared (FTIR) spectra were acquired via FTIR Bruker (VERTEX 70) using the liquid film technology. A high-resolution mass spectrum (HRMS) was obtained using the Bruker micrOTOF-Q II instrument. Melting points of the products were determined by a microscopic melting point meter (Yu Hua Instrument, $\mathrm{X}-4$ ).

\section{A typical procedure for the reaction of 2-methyl-1 $\mathrm{H}$-indole with ethyl pyruvate (the model reaction)}

The reaction was carried out in a $10 \mathrm{ml}$ V-type flask equipped with triangle magnetic stirring. In a typical reaction, 1a (19.11 $\mathrm{mg}, 0.03 \mathrm{mmol}$ ) was mixed with 2-methylindole 2a (39.354 $\mathrm{mg}, 0.3 \mathrm{mmol}$ ) and ethyl pyruvate 3a $(34.857 \mathrm{mg}$, $0.3 \mathrm{mmol}$ ) in $0.5 \mathrm{ml}$ of butyl acetate. The mixture was stirred for $30 \mathrm{~min}$ at $80{ }^{\circ} \mathrm{C}$. After the completion of the reaction, the mixture was cooled down to room temperature. Butyl acetate was removed under reduced pressure and then extracted with EtOAc $(3 \times 0.5 \mathrm{ml})$. The product was obtained by isolation with preparative TLC (eluting solution: petroleum ether/ethyl acetate $=10 / 1 \mathrm{v} / \mathrm{v}$ ). The desired product $4 \mathrm{a}$ was obtained in a $90-91 \%$ yield. At the end, the Brønsted acid ionic liquid catalyst was recycled several times; a sodium chloride solution $(3 \times 0.5 \mathrm{ml})$ was added to dissolve the ionic liquid; then, EtOAc $(3 \times 0.5 \mathrm{ml})$ was added to extract the remaining desired product. Tests for substrate scope were achieved according to the model reaction conditions.

\section{A typical procedure for the reaction of 2,5-dimethyl-1 $\mathrm{H}$-indole/ 5-methoxy-2-methyl-1H-indole with ethyl pyruvate}

The reaction was carried out in a $10 \mathrm{ml}$ V-type flask equipped with triangle magnetic stirring. In a typical reaction, 1a $(19.11 \mathrm{mg}$, $0.03 \mathrm{mmol}$ ) was mixed with 2,5-dimethyl- $1 H$-indole $(43.561 \mathrm{mg}$, $0.3 \mathrm{mmol} / 5$-methoxy-2-methyl- $1 H$-indole $(48.361 \mathrm{mg}, 0.3 \mathrm{mmol}$ ) and ethyl pyruvate $3 \mathrm{a}(34.857 \mathrm{mg}, 0.3 \mathrm{mmol})$ in $0.5 \mathrm{ml}$ of butyl acetate. The mixture was stirred for $2 \mathrm{~h}$ at $80{ }^{\circ} \mathrm{C}$. After the completion of the reaction, the mixture was cooled down to room temperature. Butyl acetate was removed under reduced pressure and then extracted with EtOAc $(3 \times 0.5 \mathrm{ml})$. The product was obtained by isolation with preparative TLC (eluting solution: petroleum ether/ethyl acetate $=10 / 1 \mathrm{v} / \mathrm{v}$ ). The desired products $\mathbf{5 r}$ and $5 \mathrm{~s}$ were obtained in a $91 \%$ and $87 \%$ yield, respectively.

\section{A typical procedure for the reaction of 1-methyl-1H-indole with ethyl pyruvate}

The reaction was carried out in a $10 \mathrm{ml} \mathrm{V}$-type flask equipped with triangle magnetic stirring. In a typical reaction, 1a (19.11 $\mathrm{mg}, \quad 0.03 \mathrm{mmol}$ ) was mixed with 1-methylindole (39.354 $\mathrm{mg}, 0.3 \mathrm{mmol}$ ) and ethyl pyruvate $3 \mathrm{a}(34.857 \mathrm{mg}$, $0.3 \mathrm{mmol}$ ) in $1 \mathrm{ml}$ of butyl acetate. The mixture was stirred for $1 \mathrm{~h}$ at $80^{\circ} \mathrm{C}$. After the completion of the reaction, the mixture was cooled down to room temperature. Butyl acetate and the product were separated from the ionic liquid phase to reuse the ionic liquid, and then, butyl acetate was distilled for reuse; subsequently, the product remained in the ionic liquid phase, which was dissolved in EtOAc $(1 \mathrm{ml})$. The product was obtained by isolation with preparative TLC (eluting solution: petroleum ether/ethyl acetate $=10 / 1 \mathrm{v} / \mathrm{v}$ ). The desired product 5 a was obtained in an 89-91\% yield. At the end, the Brønsted acid ionic liquid catalyst was recycled several times; after this, a sodium chloride $(3 \times 0.5 \mathrm{ml})$ solution was added to dissolve the ionic liquid; then, EtOAc $(3 \times 0.5 \mathrm{ml})$ was added to extract the remaining desired product.

\section{Cell lines}

The HeLa cells and A549 cells were purchased from Shanghai Zhong Qiao Xin Zhou Biotechnology Co., Ltd. The cells were cultured in the Dulbecco's modified Eagle medium (Hyclone, Thermo Scientific) and supplemented with $10 \%$ fetal bovine serum (Zhejiang Tianhang Biotechnology Co., Ltd). The cells were cultured under a $5 \% \mathrm{CO}_{2}$ atmosphere at $37^{\circ} \mathrm{C}$.

\section{In vitro cytotoxicity study (MTT assay)}

Cytotoxicity was estimated using an MTT assay. The cells were seeded in 96-well plates and cultured overnight to reach a $\sim 80 \%$ confluency. Fresh media containing the compounds were incubated with cells for $48 \mathrm{~h}$. Then, $100 \mu \mathrm{l}$ of $0.5 \mathrm{mg} \mathrm{ml}$ thiazolyl blue tetrazolium bromide (MTT, in the DMEM medium) solution was added to each well, followed by a $4 \mathrm{~h}$ incubation at $37^{\circ} \mathrm{C}$. Then, the medium was removed, and $150 \mu \mathrm{l}$ dimethyl sulfoxide (DMSO) was added. The optical density of the final solution was measured by a micro plate reader at the wavelength of $490 \mathrm{~nm}$.

\section{Spectroscopic data of the obtained products}

Ethyl 2-(2-methyl-1H-indol-3-yl)acrylate (4a). 1a (19.11 mg, $0.03 \mathrm{mmol}$ ) was mixed with 2-methyl indole (39.35 $\mathrm{mg}, 0.3$ $\mathrm{mmol}$ ) and ethyl pyruvate $(34.58 \mathrm{mg}, 0.3 \mathrm{mmol})$ to obtain $4 \mathrm{a}$ in a $91 \%$ yield $(62.58 \mathrm{mg})$; a red oil: ${ }^{1} \mathrm{H} \mathrm{NMR}\left(400 \mathrm{MHz}, \mathrm{CDCl}_{3}\right.$, $\left.25{ }^{\circ} \mathrm{C}, \mathrm{TMS}\right): \delta=7.95(\mathrm{~s}, 1 \mathrm{H}), 7.33(\mathrm{~s}, 1 \mathrm{H}), 6.99-6.98(\mathrm{~m}, 3 \mathrm{H}), 6.44$ (s, 1H), $5.69(\mathrm{~s}, 1 \mathrm{H}), 4.19(\mathrm{q}, J=7.1 \mathrm{~Hz}, 2 \mathrm{H}), 2.09(\mathrm{~s}, 3 \mathrm{H})$, $1.20 \mathrm{ppm}(\mathrm{t}, J=7.1 \mathrm{~Hz}, 3 \mathrm{H}) ;{ }^{13} \mathrm{C}$ NMR $\left(100 \mathrm{MHz}, \mathrm{CDCl}_{3}\right) \delta=$ $167.8,135.1,134.7,133.6,127.9$, 127.2, 121.3, 119.8, 118.8, 110.6, 109.6, 77.1, 61.2, 14.3, 12.5 ppm. IR ( $\left.\mathrm{cm}^{-1}\right): 3394,3055$, 2981, 293 351, 1708, 1614, 1550, 1459, 1370, 1281, 1177. HRMSESI $(m / z)$ calcd for $\mathrm{C}_{14} \mathrm{H}_{15} \mathrm{NO}_{2},[\mathrm{M}+\mathrm{Na}]^{+} 229.1103$, found 252.0997. 
Ethyl 2-(4-bromo-1-methyl-1 $H$-indol-3-yl)acrylate (4b). 1a (19.11 $\mathrm{mg}, 0.03 \mathrm{mmol}$ ) was mixed with 4-bromo-1-methyl-1 $\mathrm{H}_{\text {- }}$ indole (63.02 $\mathrm{mg}, 0.3 \mathrm{mmol}$ ) and ethyl pyruvate $(34.58 \mathrm{mg}, 0.3$ $\mathrm{mmol}$ ) to obtain $\mathbf{4 b}$ in a $90 \%$ yield $(82.9 \mathrm{mg})$; a gum-like white oil: ${ }^{1} \mathrm{H}$ NMR (400 MHz, DMSO, $25{ }^{\circ} \mathrm{C}$, TMS): $\delta=7.48(\mathrm{~d}, J=$ $8.2 \mathrm{~Hz}, 1 \mathrm{H}), 7.43(\mathrm{~s}, 1 \mathrm{H}), 7.24(\mathrm{~d}, J=7.5 \mathrm{~Hz}, 1 \mathrm{H}), 7.08(\mathrm{t}, J=$ $7.9 \mathrm{~Hz}, 1 \mathrm{H}), 6.28(\mathrm{~s}, 1 \mathrm{H}), 5.78(\mathrm{~s}, 1 \mathrm{H}), 4.15(\mathrm{q}, J=7.1 \mathrm{~Hz}, 2 \mathrm{H})$, 3.79 (s, 3H), $1.15 \mathrm{ppm}(\mathrm{t}, J=7.1 \mathrm{~Hz}, 3 \mathrm{H}) ;{ }^{13} \mathrm{C}$ NMR $(100 \mathrm{MHz}$, DMSO, $\left.25{ }^{\circ} \mathrm{C}\right) \delta=167.4,138.1,135.9,131.4,127.1,125.6,123.7$, 123.0, 113.8, 112.6, 110.2, 61.0, 40.0, 33.1, $14.5 \mathrm{ppm}$. IR ( $\left.\mathrm{cm}^{-1}\right)$ : 2929, 1721, 1606, 1456, 1347, 1165. HRMS-ESI $(\mathrm{m} / \mathrm{z})$ calcd for $\mathrm{C}_{14} \mathrm{H}_{14} \mathrm{BrNO}_{2},[\mathrm{M}+\mathrm{Na}]^{+}$330.0106, found 330.0101.

Ethyl 2-(1-ethyl-2-methyl-1H-indol-3-yl)acrylate (4c). 1a (19.11 $\mathrm{mg}, 0.03 \mathrm{mmol}$ ) was mixed with 1-ethyl-2-methyl-1 $\mathrm{H}_{\text {- }}$ indole (47.76 mg, $03 \mathrm{mmol}$ ) and ethyl pyruvate $(34.58 \mathrm{mg}, 0.3$ mmol) to obtain $4 \mathrm{c}$ in a $96 \%$ yield $(74.11 \mathrm{mg})$; a yellow oil: ${ }^{1} \mathrm{H}$ NMR (400 MHz, $\left.\mathrm{CDCl}_{3}, 25{ }^{\circ} \mathrm{C}, \mathrm{TMS}\right): \delta=7.36(\mathrm{~d}, J=7.7 \mathrm{~Hz}, 1 \mathrm{H})$, $7.18(\mathrm{~d}, J=8.1 \mathrm{~Hz}, 1 \mathrm{H}), 7.06(\mathrm{t}, J=7.4 \mathrm{~Hz}, 1 \mathrm{H}), 6.99(\mathrm{t}, J=7.4 \mathrm{~Hz}$, $1 \mathrm{H}), 6.46(\mathrm{~s}, 1 \mathrm{H}), 5.69(\mathrm{~s}, 1 \mathrm{H}), 4.18(\mathrm{q}, J=7.1 \mathrm{~Hz}, 2 \mathrm{H}), 4.03(\mathrm{q}, J=$ $7.1 \mathrm{~Hz}, 2 \mathrm{H}), 2.25(\mathrm{~s}, 3 \mathrm{H}), 1.25(\mathrm{t}, J=7.2 \mathrm{~Hz}, 3 \mathrm{H}), 1.20 \mathrm{ppm}(\mathrm{t}, J=$ $7.1 \mathrm{~Hz}, 3 \mathrm{H}) ;{ }^{13} \mathrm{C} \mathrm{NMR}\left(100 \mathrm{MHz}, \mathrm{CDCl}_{3}, 25{ }^{\circ} \mathrm{C}\right) \delta=167.8,135.5$, 135.1, 134.2, 127.5, 127.3, 121.0, 119.6, 119.0, 109.4, 108.9, 61.1, 38.0, 15.3, 14.3, $11.3 \mathrm{ppm}$. IR ( $\left.\mathrm{cm}^{-1}\right): 3050,2979,2934,1717$, 1616, 1466, 1371, 1349, 1194, 1142. HRMS-ESI $(\mathrm{m} / \mathrm{z})$ calcd for $\mathrm{C}_{16} \mathrm{H}_{19} \mathrm{NO}_{2},[\mathrm{M}+\mathrm{Na}]^{+} 280.1314$, found 280.1309.

Ethyl 2-(6-fluoro-2-methyl-1H-indol-3-yl)acrylate (4d). 1a (19.11 mg, $0.03 \mathrm{mmol}$ ) was mixed with 6-fluoro-2-methyl-1Hindole ( $44.75 \mathrm{mg}, 0.3 \mathrm{mmol}$ ) and ethyl pyruvate $(34.58 \mathrm{mg}, 0.3$ $\mathrm{mmol})$ to obtain $4 \mathbf{d}$ in a $93 \%$ yield $(68.98 \mathrm{mg})$; a yellow oil: ${ }^{1} \mathrm{H}$ NMR (400 MHz, $\left.\mathrm{CDCl}_{3}, 25{ }^{\circ} \mathrm{C}, \mathrm{TMS}\right): \delta=8.20$ (s, 1H), $7.06(\mathrm{dd}, J$ $=9.7,1.5 \mathrm{~Hz}, 1 \mathrm{H}), 6.96(\mathrm{dd}, J=8.7,4.4 \mathrm{~Hz}, 1 \mathrm{H}), 6.80(\mathrm{td}, J=9.1$, $2.1 \mathrm{~Hz}, 1 \mathrm{H}), 6.53(\mathrm{~s}, 1 \mathrm{H}), 5.77$ (s, 1H), 4.29 (q, $J=7.1 \mathrm{~Hz}, 2 \mathrm{H})$, $2.19(\mathrm{~s}, 3 \mathrm{H}), 1.31 \mathrm{ppm}(\mathrm{t}, J=7.1 \mathrm{~Hz}, 3 \mathrm{H}) ;{ }^{13} \mathrm{C}$ NMR $(100 \mathrm{MHz}$, $\left.\mathrm{CDCl}_{3}, 25{ }^{\circ} \mathrm{C}\right) \delta=167.6(\mathrm{~s}), 159.3(\mathrm{~s}), 157.0(\mathrm{~s}), 135.5(\mathrm{~s}), 134.3(\mathrm{~s})$, 131.5 (s), 128.4 (d, $J=9.9 \mathrm{~Hz}), 127.50(\mathrm{~s}), 111.0(\mathrm{~d}, J=9.6 \mathrm{~Hz})$, 109.8 (d, $J=4.1 \mathrm{~Hz}), 109.5$ (s), 109.2 (s), 104.0 (s), 103.8 (s), 61.3 (s), $14.2(\mathrm{~s}), 12.6 \mathrm{ppm}(\mathrm{s}) .{ }^{19} \mathrm{~F}$ NMR $\left(375 \mathrm{MHz}, \mathrm{CDCl}_{3}\right) \delta=$ -124.39 to $-124.58(\mathrm{~m}) \mathrm{ppm}$. IR $\left(\mathrm{cm}^{-1}\right)$ : 3359, 2983, 2933, 1703, $1613,1486,1303,1188,1146$. HRMS-ESI $(\mathrm{m} / \mathrm{z})$ calcd for $\mathrm{C}_{14} \mathrm{H}_{14} \mathrm{FNO}_{2},[\mathrm{M}+\mathrm{Na}]^{+} 270.0907$, found 270.0902 .

Ethyl 2-(2-phenyl-1H-indol-3-yl)acrylate (4e). 1a $(19.11 \mathrm{mg}$, $0.03 \mathrm{mmol}$ ) was mixed with 2-phenyl- $1 H$-indole $(57.97 \mathrm{mg}, 0.3$ $\mathrm{mmol}$ ) and ethyl pyruvate $(34.58 \mathrm{mg}, 0.3 \mathrm{mmol})$ to obtain $4 \mathrm{e}$ in an $88 \%$ yield $(76.91 \mathrm{mg})$; a yellow pale oil: ${ }^{1} \mathrm{H}$ NMR $(400 \mathrm{MHz}$, $\left.\mathrm{CDCl}_{3}, 25^{\circ} \mathrm{C}, \mathrm{TMS}\right): \delta=8.78(\mathrm{~s}, 1 \mathrm{H}), 7.60(\mathrm{~d}, J=7.6 \mathrm{~Hz}, 1 \mathrm{H}), 7.49$ $(\mathrm{d}, J=7.4 \mathrm{~Hz}, 2 \mathrm{H}), 7.36(\mathrm{t}, J=7.7 \mathrm{~Hz}, 3 \mathrm{H}), 7.29(\mathrm{t}, J=7.1 \mathrm{~Hz}$, $1 \mathrm{H}), 7.25-7.13(\mathrm{~m}, 2 \mathrm{H}), 6.59(\mathrm{~s}, 1 \mathrm{H}), 6.00(\mathrm{~s}, 1 \mathrm{H}), 3.86(\mathrm{q}, J=$ $7.1 \mathrm{~Hz}, 2 \mathrm{H}), 0.86 \mathrm{ppm}(\mathrm{t}, J=7.1 \mathrm{~Hz}, 3 \mathrm{H}) ;{ }^{13} \mathrm{C}$ NMR $(100 \mathrm{MHz}$, $\left.\mathrm{CDCl}_{3}, 25^{\circ} \mathrm{C}\right) \delta=167.6,135.9,135.9,135.1,133.2,128.8,128.6$, $128.1,127.8,127.5,122.5,120.4,119.3,111.2$, 109.8, 60.9, 13.7 ppm. IR ( $\left.\mathrm{cm}^{-1}\right): 3330,3056,2980,2802,1701,1618,1455$, 1276, 1184. HRMS-ESI $(m / z)$ calcd for $\mathrm{C}_{19} \mathrm{H}_{17} \mathrm{NO}_{2},[\mathrm{M}+\mathrm{Na}]^{+}$ 314.1157, found 314.1151.

Ethyl 2-(1-methyl-2-phenyl-1H-indol-3-yl)acrylate (4f). 1a (19.11 $\mathrm{mg}, 0.03 \mathrm{mmol}$ ) was mixed with 1-methyl-2-phenyl-1 $\mathrm{H}_{\text {- }}$ indole $(62.18 \mathrm{mg}, 0.3 \mathrm{mmol})$ and ethyl pyruvate $(34.58 \mathrm{mg}, 0.3$ mmol) to obtain 4 f in a $91 \%$ yield $(83.36 \mathrm{mg})$; a yellow pale oil: ${ }^{1} \mathrm{H} \mathrm{NMR}\left(400 \mathrm{MHz}, \mathrm{CDCl}_{3}, 25{ }^{\circ} \mathrm{C}, \mathrm{TMS}\right): \delta=7.52(\mathrm{~d}, J=7.9 \mathrm{~Hz}$, $1 \mathrm{H}), 7.29(\mathrm{dt}, J=25.5,9.5 \mathrm{~Hz}, 6 \mathrm{H}), 7.16(\mathrm{t}, J=7.3 \mathrm{~Hz}, 1 \mathrm{H}), 7.07$ $(\mathrm{t}, J=7.3 \mathrm{~Hz}, 1 \mathrm{H}), 6.29(\mathrm{~s}, 1 \mathrm{H}), 5.73(\mathrm{~s}, 1 \mathrm{H}), 3.72(\mathrm{q}, J=7.1 \mathrm{~Hz}$, $2 \mathrm{H}), 3.55(\mathrm{~s}, 3 \mathrm{H}), 0.88 \mathrm{ppm}(\mathrm{t}, J=7.1 \mathrm{~Hz}, 3 \mathrm{H}) ;{ }^{13} \mathrm{C}$ NMR (100 $\left.\mathrm{MHz}, \mathrm{CDCl}_{3}, 25^{\circ} \mathrm{C}\right) \delta=167.8,139.1,137.3,135.3,132.00,130.5$, 128.5, 128.2, 127.2, 127.0, 122.2, 120.4, 119.5, 110.7, 109.8, 60.8, 31.1, 14.0 ppm. IR ( $\left.\mathrm{cm}^{-1}\right): 3054,2980,2937,1889,1717,1613$, 1467, 1371, 1226, 1099. IR ( $\left.\mathrm{cm}^{-1}\right): 3054,2979,2901,1718,1614$, $1462,1345,1264,1213,1104$. HRMS-ESI $(\mathrm{m} / \mathrm{z})$ calcd for $\mathrm{C}_{20} \mathrm{H}_{19} \mathrm{NO}_{2}$, [M $\left.+\mathrm{Na}\right]^{+}$328.1314, found 328.1308.

Ethyl 2-(1-ethyl-2-phenyl-1H-indol-3-yl)acrylate (4g). $1 \mathrm{a}$ (19.11 $\mathrm{mg}, 0.03 \mathrm{mmol}$ ) was mixed with 1-ethyl-2-phenyl-1 $H$ indole (66.39 mg, $0.3 \mathrm{mmol}$ ) and ethyl pyruvate $(34.58 \mathrm{mg}, 0.3$ $\mathrm{mmol}$ ) to obtain $4 \mathrm{~g}$ in a $91 \%$ yield $(86.23 \mathrm{mg})$; a yellow pale oil: ${ }^{1} \mathrm{H}$ NMR (400 MHz, $\left.\mathrm{CDCl}_{3}, 25{ }^{\circ} \mathrm{C}, \mathrm{TMS}\right): \delta=7.53(\mathrm{~d}, J=7.8 \mathrm{~Hz}$, $1 \mathrm{H}), 7.35-7.25(\mathrm{~m}, 6 \mathrm{H}), 7.15(\mathrm{t}, J=7.3 \mathrm{~Hz}, 1 \mathrm{H}), 7.07(\mathrm{t}, J=7.3 \mathrm{~Hz}$, $1 \mathrm{H}), 6.25(\mathrm{~s}, 1 \mathrm{H}), 5.71(\mathrm{~s}, 1 \mathrm{H}), 4.02(\mathrm{q}, J=7.1 \mathrm{~Hz}, 2 \mathrm{H}), 3.73(\mathrm{q}, J=$ $7.1 \mathrm{~Hz}, 2 \mathrm{H}), 1.17(\mathrm{t}, J=7.1 \mathrm{~Hz}, 3 \mathrm{H}), 0.91 \mathrm{ppm}(\mathrm{t}, J=7.1 \mathrm{~Hz}, 3 \mathrm{H})$; ${ }^{13} \mathrm{C} \mathrm{NMR}\left(100 \mathrm{MHz}, \mathrm{CDCl}_{3}, 25{ }^{\circ} \mathrm{C}\right) \delta=167.8,138.7,136.1,135.3$, $132.3,130.5,128.5,128.3,127.5,126.8,122.1,120.3,119.7$, 111.0, 110.0, 60.7, 38.9, 15.4, 14.0 ppm. IR $\left(\mathrm{cm}^{-1}\right): 3054,2979$, 2935, 1718, 1614, 1462, 1345, 1213, 1142, 1104, 1026. HRMS-ESI $(\mathrm{m} / \mathrm{z})$ calcd for $\mathrm{C}_{21} \mathrm{H}_{21} \mathrm{NO}_{2},[\mathrm{M}+\mathrm{Na}]^{+} 342.1470$, found 342.1464.

Ethyl 2-(5-chloro-2-methyl-1H-indol-3-yl)acrylate (4h). 1a (19.11 $\mathrm{mg}, 0.03 \mathrm{mmol}$ ) was mixed with 5-chloro-2-methyl-1 $\mathrm{H}_{\text {- }}$ indole (49.68 mg, $0.3 \mathrm{mmol}$ ) and ethyl pyruvate $(34.58 \mathrm{mg}, 0.3$ $\mathrm{mmol})$ to obtain $\mathbf{4 h}$ in a $92 \%$ yield $(72.78 \mathrm{mg})$; a yellow oil: ${ }^{1} \mathrm{H}$ NMR (400 MHz, $\left.\mathrm{CDCl}_{3}, 25{ }^{\circ} \mathrm{C}, \mathrm{TMS}\right): \delta=8.12(\mathrm{~s}, 1 \mathrm{H}), 7.38(\mathrm{~s}$, $1 \mathrm{H}), 7.06(\mathrm{q}, J=8.5 \mathrm{~Hz}, 2 \mathrm{H}), 6.57(\mathrm{~s}, 1 \mathrm{H}), 5.79(\mathrm{~s}, 1 \mathrm{H}), 4.29(\mathrm{q}, J=$ $7.0 \mathrm{~Hz}, 2 \mathrm{H}), 2.27(\mathrm{~s}, 3 \mathrm{H}), 1.32 \mathrm{ppm}(\mathrm{t}, J=7.1 \mathrm{~Hz}, 3 \mathrm{H}) ;{ }^{13} \mathrm{C} \mathrm{NMR}$ $\left(100 \mathrm{MHz}, \mathrm{CDCl}_{3}, 25^{\circ} \mathrm{C}\right) \delta=167.3,134.9,134.1,133.4,129.1$, 128.0, 125.6, 121.5, 118.4, 111.3, 109.6, 61.2, 14.2, 12.6 ppm. IR ( $\mathrm{cm}^{-1}$ ): 3349, 2982, 2928, 1701, 1617, 1472, 1302, 1175, 1083. HRMS-ESI $(\mathrm{m} / \mathrm{z})$ calcd for $\mathrm{C}_{14} \mathrm{H}_{14} \mathrm{ClNO}_{2},[\mathrm{M}+\mathrm{Na}]^{+} 286.06053$, found 286.06084.

Ethyl 3-(3-ethoxy-3-oxoprop-1-en-2-yl)-1H-indole-2-carboxylate (4i). 1a (19.11 mg, $0.03 \mathrm{mmol})$ was mixed with ethyl $1 H$-indole2-carboxylate (56.76 $\mathrm{mg}, \quad 0.3 \mathrm{mmol})$ and ethyl pyruvate (34.58 $\mathrm{mg}, 0.3 \mathrm{mmol}$ ) to obtain $4 \mathbf{i}$ in a $93 \%$ yield $(80.15 \mathrm{mg}$ ); a yellow pale oil: ${ }^{1} \mathrm{H}$ NMR (400 MHz, $\left.\mathrm{CDCl}_{3}, 25{ }^{\circ} \mathrm{C}, \mathrm{TMS}\right): \delta=9.47$ $(\mathrm{s}, 1 \mathrm{H}), 7.63(\mathrm{~d}, J=8.1 \mathrm{~Hz}, 1 \mathrm{H}), 7.40(\mathrm{~d}, J=8.3 \mathrm{~Hz}, 1 \mathrm{H}), 7.31(\mathrm{t}, J=$ $7.6 \mathrm{~Hz}, 1 \mathrm{H}), 7.16$ (t, J = 7.5 Hz, 1H), $6.66(\mathrm{~s}, 1 \mathrm{H}), 5.92(\mathrm{~s}, 1 \mathrm{H}), 4.32$ (q, $J=7.1 \mathrm{~Hz}, 2 \mathrm{H}), 4.24(\mathrm{q}, J=7.1 \mathrm{~Hz}, 2 \mathrm{H}), 1.34(\mathrm{t}, J=7.1 \mathrm{~Hz}, 3 \mathrm{H})$, $1.25 \mathrm{ppm}(\mathrm{t}, J=7.1 \mathrm{~Hz}, 3 \mathrm{H}) ;{ }^{13} \mathrm{C} \mathrm{NMR}\left(100 \mathrm{MHz}, \mathrm{CDCl}_{3}, 25^{\circ} \mathrm{C}\right) \delta=$ 167.1, 161.8, 135.9, 134.5, 128.1, 127.4, 125.6, 124.3, 121.0, 120.8, 118.4, 112.1, 61.2, 61.0, 14.2 ppm. IR ( $\left.\mathrm{cm}^{-1}\right): 3332,3062,2983$, 2904, 1707, 1538, 1461, 1246, 1023. HRMS-ESI $(\mathrm{m} / \mathrm{z})$ calcd for $\mathrm{C}_{21} \mathrm{H}_{21} \mathrm{NO}_{2},[\mathrm{M}+\mathrm{Na}]^{+} 319.1572$, found 342.1464.

Ethyl 3-(3-ethoxy-3-oxoprop-1-en-2-yl)-5-methoxy-1H-indole2-carboxylate (4j). 1a $(19.11 \mathrm{mg}, 0.03 \mathrm{mmol})$ was mixed with ethyl 5-methoxy- $1 H$-indole-2-carboxylate $(65.77 \mathrm{mg}, 0.3 \mathrm{mmol})$ and ethyl pyruvate $(34.58 \mathrm{mg}, 0.3 \mathrm{mmol}$ ) to obtain $4 \mathbf{j}$ in an $80 \%$ yield (76.16 mg); a yellow pale oil: ${ }^{1} \mathrm{H} \mathrm{NMR}$ (400 $\mathrm{MHz}, \mathrm{CDCl}_{3}$, $\left.25{ }^{\circ} \mathrm{C}, \mathrm{TMS}\right): \delta=9.03(\mathrm{~s}, 4 \mathrm{H}), 7.32(\mathrm{~d}, J=8.6 \mathrm{~Hz}, 5 \mathrm{H}), 7.02(\mathrm{~s}$, $9 \mathrm{H}), 6.66(\mathrm{~s}, 5 \mathrm{H}), 5.92(\mathrm{~s}, 5 \mathrm{H}), 4.33(\mathrm{q}, J=7.1 \mathrm{~Hz}, 10 \mathrm{H}), 4.23(\mathrm{q}, J$ $=7.1 \mathrm{~Hz}, 10 \mathrm{H}), 3.84(\mathrm{~s}, 15 \mathrm{H}), 1.35(\mathrm{t}, J=7.1 \mathrm{~Hz}, 16 \mathrm{H}), 1.26 \mathrm{ppm}$ 
$(\mathrm{t}, J=7.0 \mathrm{~Hz}, 18 \mathrm{H}) ;{ }^{13} \mathrm{C} \mathrm{NMR}\left(100 \mathrm{MHz}, \mathrm{CDCl}_{3}, 25^{\circ} \mathrm{C}\right) \delta=167.1$, 161.2 , 155.1, 134.6, 131.1, 127.9, 127.8, 124.8, 118.1, 117.4, 112.9, 100.8, 61.1, 61.0, 55.7, 14.2 ppm. IR $\left(\mathrm{cm}^{-1}\right): 3330,2983$, 2935, 1707, 1625, 1468, 1215, 1028. HRMS-ESI $(\mathrm{m} / \mathrm{z})$ calcd for $\mathrm{C}_{16} \mathrm{H}_{17} \mathrm{NO}_{4},[\mathrm{M}+\mathrm{Na}]^{+} 310.1056$, found 310.1050.

Ethyl 3-(3-ethoxy-3-oxoprop-1-en-2-yl)-5-fluoro-1 $\mathrm{H}$-indole-2carboxylate (4k). 1a (19.11 mg, $0.03 \mathrm{mmol})$ was mixed with ethyl 5-fluoro- $1 H$-indole-2-carboxylate $(62.16 \mathrm{mg}, 0.3 \mathrm{mmol})$ and ethyl pyruvate $(34.58 \mathrm{mg}, 0.3 \mathrm{mmol})$ to obtain $4 \mathbf{k}$ in a $70 \%$ yield (64.11 mg); a white solid: $\mathrm{mp}=132-133{ }^{\circ} \mathrm{C} ;{ }^{1} \mathrm{H}$ NMR $(400 \mathrm{MHz}$, $\mathrm{CDCl}_{3}, 25{ }^{\circ} \mathrm{C}$, TMS): $\delta=9.10(\mathrm{~s}, 2 \mathrm{H}), 7.36(\mathrm{dd}, J=8.9,4.2 \mathrm{~Hz}$, $2 \mathrm{H}), 7.25(\mathrm{~s}, 2 \mathrm{H}), 7.11(\mathrm{td}, J=8.9,2.0 \mathrm{~Hz}, 2 \mathrm{H}), 6.65(\mathrm{~s}, 2 \mathrm{H}), 5.90$ $(\mathrm{s}, 2 \mathrm{H}), 4.34(\mathrm{q}, J=7.1 \mathrm{~Hz}, 4 \mathrm{H}), 4.26(\mathrm{~s}, 4 \mathrm{H}), 1.35(\mathrm{t}, J=7.1 \mathrm{~Hz}$, $7 \mathrm{H}), 1.27 \mathrm{ppm}(\mathrm{d}, J=7.1 \mathrm{~Hz}, 7 \mathrm{H}) ;{ }^{13} \mathrm{C} \mathrm{NMR}\left(100 \mathrm{MHz}, \mathrm{CDCl}_{3}, 25\right.$ $\left.{ }^{\circ} \mathrm{C}\right) \delta=166.8(\mathrm{~s}), 161.3(\mathrm{~s}), 159.7(\mathrm{~s}), 134.1(\mathrm{~s}), 132.3(\mathrm{~s}), 128.5-$ $128.3(\mathrm{~m}), 128.0(\mathrm{~d}, J=39.1 \mathrm{~Hz}), 125.9(\mathrm{~s}), 118.4(\mathrm{~s}), 115.0(\mathrm{~s})$, $114.8(\mathrm{~s}), 113.0$ (d, $J=9.4 \mathrm{~Hz}), 105.4(\mathrm{~s}), 105.2(\mathrm{~s}), 61.4(\mathrm{~s}), 61.0$ (s), $29.3(\mathrm{~s}), 14.2 \mathrm{ppm}(\mathrm{s}) .{ }^{19} \mathrm{~F}$ NMR $\left(375 \mathrm{MHz}, \mathrm{CDCl}_{3}\right) \delta=$ -121.96 to $-122.02(\mathrm{~m}) \mathrm{ppm}$. IR $\left(\mathrm{cm}^{-1}\right)$ : 3392, 3312, 2956, 2922, 2851, 1712, 1470, 1248, 1186. HRMS-ESI $(\mathrm{m} / \mathrm{z})$ calcd for $\mathrm{C}_{16} \mathrm{H}_{16} \mathrm{FNO}_{4},[\mathrm{M}+\mathrm{Na}]^{+}$328.0961, found 328.0955.

3-(2-Methyl-1H-indol-3-yl)but-3-en-2-one (4l). 1a $(19.11 \mathrm{mg}$, $0.03 \mathrm{mmol})$ was mixed with 2 -methyl- $1 H$-indole $(39.35 \mathrm{mg}, 0.3$ $\mathrm{mmol}$ ) and methyl pyruvate $(25.82 \mathrm{mg}, 0.3 \mathrm{mmol})$ to obtain $4 \mathrm{lin}$ an $87 \%$ yield (52.01 mg); a yellow oil: ${ }^{1} \mathrm{H}$ NMR (400 $\mathrm{MHz}, \mathrm{CDCl}_{3}$, $\left.25{ }^{\circ} \mathrm{C}, \mathrm{TMS}\right): \delta=8.08(\mathrm{~s}, 3 \mathrm{H}), 7.35$ (d, $\left.J=7.6 \mathrm{~Hz}, 3 \mathrm{H}\right), 7.27-7.23$ (m, 4H), 7.15-7.06 (m, 7H), $6.36(\mathrm{~s}, 3 \mathrm{H}), 5.83(\mathrm{~s}, 3 \mathrm{H}), 2.38(\mathrm{~s}, 9 \mathrm{H})$, $2.30 \mathrm{ppm}(\mathrm{s}, 9 \mathrm{H}) ;{ }^{13} \mathrm{C} \mathrm{NMR}\left(100 \mathrm{MHz}, \mathrm{CDCl}_{3}, 25{ }^{\circ} \mathrm{C}\right) \delta=200.8$, $142.9,135.2$, 133.1, 128.1, 126.2, 121.5, 120.0, 118.6, 110.4, 110.2, 27.4, 12.6 ppm. IR ( $\left.\mathrm{cm}^{-1}\right): 3393,3056,2923,2853,1678$, $1604,1460,1359$. HRMS-ESI $(\mathrm{m} / \mathrm{z})$ calcd for $\mathrm{C}_{13} \mathrm{H}_{13} \mathrm{NO},[\mathrm{M}+\mathrm{Na}]^{+}$ 222.08894, found 222.08925.

Methyl 2-(2-methyl-1H-indol-3-yl)acrylate (4m). 1a (19.11 mg, $0.03 \mathrm{mmol}$ ) was mixed with 2-methyl- $1 H$-indole $(39.35 \mathrm{mg}, 0.3$ $\mathrm{mmol}$ ) and methyl 2-oxopropanoate $(30.78 \mathrm{mg}, 0.3 \mathrm{mmol})$ to obtain $4 \mathrm{~m}$ in a 95\% yield (61.34 mg); a yellow oil: ${ }^{1} \mathrm{H}$ NMR (400 $\left.\mathrm{MHz} \mathrm{CDCl}_{3}, 25^{\circ} \mathrm{C}, \mathrm{TMS}\right): \delta=8.03(\mathrm{~s}, 1 \mathrm{H}), 7.41(\mathrm{~d}, J=6.9 \mathrm{~Hz}$, $1 \mathrm{H}), 7.17(\mathrm{~d}, J=7.6 \mathrm{~Hz}, 1 \mathrm{H}), 7.12-7.06(\mathrm{~m}, 2 \mathrm{H}), 6.55$ (s, 1H), 5.80 $(\mathrm{s}, 1 \mathrm{H}), 3.79(\mathrm{~s}, 3 \mathrm{H}), 2.26 \mathrm{ppm}(\mathrm{s}, 3 \mathrm{H}) ;{ }^{13} \mathrm{C}$ NMR $(100 \mathrm{MHz}$, $\left.\mathrm{CDCl}_{3}, 25{ }^{\circ} \mathrm{C}\right) \delta=168.2,168.2,135.0,134.2,133.4,133.4,127.9$, 127.5, 121.3, 119.9, 118.6, 110.4, 109.5, 109.5, 77.3, 77.0, 76.7, 52.1, 12.4 ppm. IR ( $\left.\mathrm{cm}^{-1}\right): 3393,3056,2950,2922,1707,1621$, $1460,1437,1285,1168$. HRMS-ESI $(\mathrm{m} / \mathrm{z})$ calcd for $\mathrm{C}_{13} \mathrm{H}_{13} \mathrm{NO}_{2}$, [M $+\mathrm{Na}]^{+} 238.08385$, found 238.08415 .

2-(2-Methyl-1H-indol-3-yl)-1-phenylprop-2-en-1-one (4n). 1a (19.11 mg, $0.03 \mathrm{mmol}$ ) was mixed with 2-methyl- $1 H$-indole (39.35 $\mathrm{mg}, \quad 0.3 \mathrm{mmol}$ ) and 1-phenylpropane-1,2-dione (44.44 $\mathrm{mg}, 0.3 \mathrm{mmol}$ ) to obtain $4 \mathrm{n}$ in a $92 \%$ yield $(72.12 \mathrm{mg}$ ); a yellow oil: ${ }^{1} \mathrm{H}$ NMR (400 $\mathrm{MHz}, \mathrm{CDCl}_{3}, 25{ }^{\circ} \mathrm{C}$, TMS) $\delta=8.02$ (brs, $1 \mathrm{H}), 7.90(\mathrm{~d}, J=7.6 \mathrm{~Hz}, 2 \mathrm{H}), 7.60-7.47(\mathrm{~m}, 2 \mathrm{H}), 7.38(\mathrm{t}, J=$ $7.5 \mathrm{~Hz}, 2 \mathrm{H}), 7.24(\mathrm{~s}, 1 \mathrm{H}), 7.11$ (dd, $J=13.6,6.9 \mathrm{~Hz}, 2 \mathrm{H}), 6.01(\mathrm{~s}$, 1H), $5.92(\mathrm{~s}, 1 \mathrm{H}), 2.22 \mathrm{ppm}(\mathrm{s}, 3 \mathrm{H}) ;{ }^{13} \mathrm{C}$ NMR (100 MHz, DMSO, $\left.25{ }^{\circ} \mathrm{C}\right) \delta=197.9,143.0,137.4,135.7,134.5,133.5,129.7,129.3$, 129.0, 128.3, 127.1, 121.4, 121.2, 119.9, 118.4, 111.3, 109.8, 13.0 ppm. IR (cm $\left.{ }^{-1}\right): 2960,2930,2871,1720,1459,1281,1062$. HRMS-ESI $(m / z)$ calcd for $\mathrm{C}_{18} \mathrm{H}_{15} \mathrm{NO},[\mathrm{M}+\mathrm{Na}]^{+} 284.10459$, found 248.10505 .
(E)-Hex-3-en-1-yl 2-(2-methyl-1H-indol-3-yl)acrylate (4o). 1a (19.11 $\mathrm{mg}, 0.03 \mathrm{mmol}$ ) was mixed with 2-methyl- $1 H$-indole (39.35 mg, $0.3 \mathrm{mmol}$ ) and (E)-hex-3-en-1-yl 2-oxopropanoate (51.06 $\mathrm{mg}, 0.3 \mathrm{mmol}$ ) to obtain 40 in a $94 \%$ yield $(79.90 \mathrm{mg}$ ); a yellow oil: ${ }^{1} \mathrm{H}$ NMR $\left(400 \mathrm{MHz}, \mathrm{CDCl}_{3}, 25{ }^{\circ} \mathrm{C}, \mathrm{TMS}\right): \delta=8.01(\mathrm{~s}$, $1 \mathrm{H}), 7.42(\mathrm{~d}, J=6.9 \mathrm{~Hz}, 1 \mathrm{H}), 7.17$ (d, $J=7.0 \mathrm{~Hz}, 1 \mathrm{H}), 7.12-7.04$ $(\mathrm{m}, 2 \mathrm{H}), 6.54(\mathrm{~s}, 1 \mathrm{H}), 5.80(\mathrm{~s}, 1 \mathrm{H}), 5.48(\mathrm{dd}, J=17.3,7.3 \mathrm{~Hz}, 1 \mathrm{H})$, $5.31(\mathrm{dd}, J=16.9,7.5 \mathrm{~Hz}, 1 \mathrm{H}), 4.22(\mathrm{~d}, J=7.0 \mathrm{~Hz}, 2 \mathrm{H}), 2.42(\mathrm{dd}, J$ $=13.6,6.7 \mathrm{~Hz}, 2 \mathrm{H}), 2.27(\mathrm{~s}, 3 \mathrm{H}), 2.06-1.97(\mathrm{~m}, 2 \mathrm{H}), 0.93 \mathrm{ppm}(\mathrm{t}, J$ $=7.5 \mathrm{~Hz}, 3 \mathrm{H}) ;{ }^{13} \mathrm{C} \mathrm{NMR}\left(100 \mathrm{MHz}, \mathrm{CDCl}_{3}, 25{ }^{\circ} \mathrm{C}\right) \delta=167.67$, 135.06, 134.7, 134.6, 133.4, 133.4, 128.0, 127.4, 123.7, 121.4, 119.9, 118.9, 110.4, 109.7, 64.7, 26.8, 20.6, 14.2, 12.6 ppm. IR $\left(\mathrm{cm}^{-1}\right):$ 3393, 3057, 2962, 2929, 1704, 1612, 1460, 1388, 1284, 1172, 1079. HRMS-ESI $(\mathrm{m} / \mathrm{z})$ calcd for $\mathrm{C}_{18} \mathrm{H}_{21} \mathrm{NO}_{2},[\mathrm{M}+\mathrm{Na}]^{+}$ 306.14645, found 306.14672.

Ethyl (E)-2-(2-methyl-1H-indol-3-yl)hex-2-enoate (4p). 1a (19.11 $\mathrm{mg}, 0.03 \mathrm{mmol})$ was mixed with 2-methyl- $H$-indole (39.35 mg, $0.3 \mathrm{mmol}$ ) and ethyl 2-oxohexanoate (47.45 mg, 0.3 $\mathrm{mmol})$ to obtain $4 \mathrm{p}$ in a $95 \%$ yield $(81.40 \mathrm{mg})$; a red solid: $\mathrm{mp}=$ 85-86 ${ }^{\circ} \mathrm{C} ;{ }^{1} \mathrm{H}$ NMR (400 MHz, $\left.\mathrm{CDCl}_{3}, 25{ }^{\circ} \mathrm{C}, \mathrm{TMS}\right): \delta=7.90(\mathrm{~s}$, $1 \mathrm{H}), 7.44(\mathrm{~d}, J=7.2 \mathrm{~Hz}, 1 \mathrm{H}), 7.18(\mathrm{~d}, J=7.7 \mathrm{~Hz}, 1 \mathrm{H}), 7.09(\mathrm{dd}, J=$ $13.1,6.6 \mathrm{~Hz}, 2 \mathrm{H}), 6.13(\mathrm{t}, J=7.5 \mathrm{~Hz}, 1 \mathrm{H}), 4.24(\mathrm{q}, J=6.9 \mathrm{~Hz}, 2 \mathrm{H})$, $2.57(\mathrm{q}, J=7.3 \mathrm{~Hz}, 2 \mathrm{H}), 2.28(\mathrm{~s}, 3 \mathrm{H}), 1.63-1.50(\mathrm{~m}, 2 \mathrm{H}), 1.25(\mathrm{t}, J$ $=7.0 \mathrm{~Hz}, 3 \mathrm{H}), 1.01 \mathrm{ppm}(\mathrm{t}, J=7.2 \mathrm{~Hz}, 3 \mathrm{H}) ;{ }^{13} \mathrm{C} \mathrm{NMR}(100 \mathrm{MHz}$, $\left.\mathrm{CDCl}_{3}, 25{ }^{\circ} \mathrm{C}\right) \delta=168.7,143.5,135.0,132.5,128.2,126.9,121.2$, $119.7,118.7,111.5,110.4,60.5,32.0,22.9,14.3,13.9,12.4$ ppm. IR (cm $\left.{ }^{-1}\right): 3396,3057,2960,2930,2870,1699,1623,1556,1460$, 1212, 1172. HRMS-ESI $(\mathrm{m} / \mathrm{z})$ calcd for $\mathrm{C}_{17} \mathrm{H}_{21} \mathrm{NO}_{2},[\mathrm{M}+\mathrm{Na}]^{+}$ 294.14645, found 294.14674.

2-Methyl-3-(3,3,3-trifluoroprop-1-en-2-yl)-1H-indole (4q). 1a (19.11 $\mathrm{mg}, 0.03 \mathrm{mmol})$ was mixed with 2-methyl- $H$-indole (39.35 $\mathrm{mg}, \quad 0.3 \mathrm{mmol}$ ) and 1,1,1-trifluoropropan-2-one (33.61 $\mathrm{mg}, 0.3 \mathrm{mmol}$ ) to obtain $\mathbf{4 q}$ in an $88 \%$ yield $(59.45 \mathrm{mg}$ ); a reddish brown oil: ${ }^{1} \mathrm{H}$ NMR (400 MHz, DMSO, $\left.25{ }^{\circ} \mathrm{C}, \mathrm{TMS}\right): \delta=$ $11.34(\mathrm{~s}, 1 \mathrm{H}), 7.33(\mathrm{dd}, J=7.3,4.2 \mathrm{~Hz}, 2 \mathrm{H}), 7.07(\mathrm{t}, J=7.4 \mathrm{~Hz}$, $1 \mathrm{H}), 7.00(\mathrm{t}, J=7.4 \mathrm{~Hz}, 1 \mathrm{H}), 6.22(\mathrm{~s}, 1 \mathrm{H}), 5.71(\mathrm{~s}, 1 \mathrm{H}), 2.35 \mathrm{ppm}$ $(\mathrm{s}, 3 \mathrm{H}) ;{ }^{13} \mathrm{C}$ NMR $\left(100 \mathrm{MHz}\right.$, DMSO, $\left.25{ }^{\circ} \mathrm{C}\right) \delta=136.0-135.8(\mathrm{~m})$, 135.5 (d, $J=17.5 \mathrm{~Hz}), 132.9$ (s), 132.6 (s), 132.3 (s), 132.0 (s), 127.9 (s), 125.5 (s), 124.6 (dd, $J=10.1,5.0 \mathrm{~Hz}$ ), 122.8 (s), 121.3 (s), 119.9 (s), 118.4 (s), 111.3 (s), 105.3 (s), $12.2 \mathrm{ppm}(\mathrm{s}) .{ }^{19} \mathrm{~F}$ NMR (375 MHz, DMSO) $\delta=-64.49$ (s). IR ( $\left.\mathrm{cm}^{-1}\right): 3478,3403,2927$, $1663,1460,1289,1168,1125$. HRMS-ESI $(\mathrm{m} / \mathrm{z})$ calcd for $\mathrm{C}_{12} \mathrm{H}_{10} \mathrm{~F}_{3} \mathrm{~N},[\mathrm{M}+\mathrm{H}]^{+}$226.08381, found 226.08416.

Diethyl (E)-4-((E)-2,5-dimethyl-3H-indol-3-ylidene)-2methylpent-2 enedioate (4r). 1a (19.11 mg, $0.03 \mathrm{mmol})$ was mixed with 2,5-dimethyl- $1 H$-indole $(43.56 \mathrm{mg}, 0.3 \mathrm{mmol})$ and ethyl pyruvate $(34.58 \mathrm{mg}, 0.3 \mathrm{mmol})$ to obtain $4 \mathbf{r}$ in a $91 \%$ yield (84.46 mg); a gum-like brown oil: ${ }^{1} \mathrm{H} \mathrm{NMR}\left(400 \mathrm{MHz}, \mathrm{CDCl}_{3}\right.$, $\left.25{ }^{\circ} \mathrm{C}, \mathrm{TMS}\right): \delta=7.81(\mathrm{~s}, 1 \mathrm{H}), 6.90(\mathrm{~d}, J=8.2 \mathrm{~Hz}, 1 \mathrm{H}), 6.72(\mathrm{~d}, J=$ $8.2 \mathrm{~Hz}, 1 \mathrm{H}), 6.00(\mathrm{~s}, 1 \mathrm{H}), 4.27$ (q, $J=7.1 \mathrm{~Hz}, 2 \mathrm{H}), 4.08$ (dd, $J=$ 13.3, $6.3 \mathrm{~Hz}, 2 \mathrm{H}), 2.32(\mathrm{~s}, 3 \mathrm{H}), 2.22(\mathrm{~s}, 3 \mathrm{H}), 1.57(\mathrm{~s}, 3 \mathrm{H}), 1.30(\mathrm{t}, J$ $=7.1 \mathrm{~Hz}, 3 \mathrm{H}), 1.13 \mathrm{ppm}(\mathrm{t}, J=7.1 \mathrm{~Hz}, 3 \mathrm{H}) ;{ }^{13} \mathrm{C} \mathrm{NMR}(100 \mathrm{MHz}$, $\left.\mathrm{CDCl}_{3}, 25^{\circ} \mathrm{C}\right) \delta=173.5,170.7,134.7,131.5,131.4,130.9,126.0$, 125.8, 124.0, 119.1, 110.8, 109.4, 61.4, 45.9, 27.2, 19.7, 14.1, 13.0 ppm. IR ( $\left.\mathrm{cm}^{-1}\right): 3392,2980,2931,1725,1453,1369,1232$, 
1100. HRMS-ESI $(\mathrm{m} / \mathrm{z})$ calcd for $\mathrm{C}_{20} \mathrm{H}_{23} \mathrm{NO}_{4},[\mathrm{M}+\mathrm{Na}]^{+} 364.1525$, found 364.1517.

Diethyl (E)-4-((E)-5-methoxy-2-methyl-3H-indol-3-ylidene)-2methylpent-2-enedioate (4s). 1a (19.11 mg, $0.03 \mathrm{mmol})$ was mixed with 5-methoxy-2-methyl- $H$-indole $(48.36 \mathrm{mg}, 0.3 \mathrm{mmol})$ and ethyl pyruvate $(34.58 \mathrm{mg}, 0.3 \mathrm{mmol})$ to obtain $4 \mathrm{~s}$ in an $87 \%$ yield (94.62 mg); a gum-like reddish brown oil: ${ }^{1} \mathrm{H}$ NMR (400 $\left.\mathrm{MHz} \mathrm{CDCl}_{3}, 25{ }^{\circ} \mathrm{C}, \mathrm{TMS}\right): \delta=7.81(\mathrm{~s}, 1 \mathrm{H}), 7.03(\mathrm{~d}, J=8.7 \mathrm{~Hz}$, $1 \mathrm{H}), 6.68(\mathrm{~d}, J=8.7 \mathrm{~Hz}, 1 \mathrm{H}), 5.89(\mathrm{~s}, 1 \mathrm{H}), 4.34(\mathrm{q}, J=7.1 \mathrm{~Hz}, 2 \mathrm{H})$, 4.15 (dd, $J=13.9,6.9 \mathrm{~Hz}, 2 \mathrm{H}), 3.78$ (s, 3H), 2.42 (s, 3H), 1.64 (s, $3 \mathrm{H}), 1.37$ (t, $J=7.1 \mathrm{~Hz}, 3 \mathrm{H}), 1.22 \mathrm{ppm}(\mathrm{t}, J=7.1 \mathrm{~Hz}, 3 \mathrm{H}) ;{ }^{13} \mathrm{C}$ NMR (100 MHz, $\left.\mathrm{CDCl}_{3}, 25{ }^{\circ} \mathrm{C}\right) \delta=173.6,170.3,148.4,133.0$, 131.2, 129.1, 127.8, 126.3, 111.4, 109.4, 109.3, 109.2, 61.4, 61.1, 57.6, 46.1, 27.4, 14.3, $13.2 \mathrm{ppm}$. IR $\left(\mathrm{cm}^{-1}\right): 3366,2980,2932$, 2836, 1725, 1503, 1452, 1276, 1233. IR $\left(\mathrm{cm}^{-1}\right): 3392,2980,2931$, 2870, 1725, 1453, 1232, 1100. HRMS-ESI $(\mathrm{m} / \mathrm{z})$ calcd for $\mathrm{C}_{20} \mathrm{H}_{23} \mathrm{NO}_{5},[\mathrm{M}+\mathrm{Na}]^{+} 380.1474$, found 380.1466.

Diethyl 1,4-dimethyl-3-(1-methyl-1H-indol-3-yl)-1,2,3,4-tetrahydrocyclopenta $[\boldsymbol{b}]$ indole-1,3-dicarboxylate (5a). 1a $(19.11 \mathrm{mg}$, $0.03 \mathrm{mmol}$ ) was mixed with 1-methyl-1H-indole $(39.35 \mathrm{mg}, 0.3$ $\mathrm{mmol}$ ) and ethyl pyruvate $(34.58 \mathrm{mg}, 0.3 \mathrm{mmol})$ to obtain $5 \mathrm{a}$ in a $92 \%$ yield $\left(126.55 \mathrm{mg}\right.$ ); a yellow solid: $\mathrm{mp}=130-131{ }^{\circ} \mathrm{C} ;{ }^{1} \mathrm{H}$ NMR (400 MHz, DMSO, $25^{\circ} \mathrm{C}$, TMS): $\delta=7.59$ (d, $J=7.6 \mathrm{~Hz}, 1 \mathrm{H}$ ), $7.42(\mathrm{~d}, J=8.2 \mathrm{~Hz}, 1 \mathrm{H}), 7.36(\mathrm{~d}, J=8.1 \mathrm{~Hz}, 1 \mathrm{H}), 7.20(\mathrm{~s}, 1 \mathrm{H}), 7.12$ $(\mathrm{dt}, J=15.1,7.3 \mathrm{~Hz}, 3 \mathrm{H}), 6.82(\mathrm{t}, J=7.4 \mathrm{~Hz}, 1 \mathrm{H}), 6.65(\mathrm{~d}, J=$ $7.9 \mathrm{~Hz}, 1 \mathrm{H}), 4.36-4.14(\mathrm{~m}, 2 \mathrm{H}), 4.02(\mathrm{dd}, J=18.8,11.6 \mathrm{~Hz}, 3 \mathrm{H})$, $3.41(\mathrm{~s}, 3 \mathrm{H}), 3.30(\mathrm{~s}, 3 \mathrm{H}), 2.67(\mathrm{~d}, J=13.6 \mathrm{~Hz}, 1 \mathrm{H}), 1.67(\mathrm{~s}, 3 \mathrm{H})$, $1.24(\mathrm{t}, J=7.0 \mathrm{~Hz}, 3 \mathrm{H}), 1.13 \mathrm{ppm}(\mathrm{t}, J=7.0 \mathrm{~Hz}, 3 \mathrm{H}) ;{ }^{13} \mathrm{C} \mathrm{NMR}$ (100 MHz, DMSO, $\left.25{ }^{\circ} \mathrm{C}\right) \delta=175.5,172.5,143.6,142.0$, 137.8, $127.4,125.5,122.5$, 121.9, 121.4, 121.0, 119.8, 119.6, 119.1, $118.8,114.3,110.8,110.6,61.7,60.8,56.8,53.9,48.1,32.8,30.7$, 25.3, 14.5, 14.4 ppm. IR ( $\left.\mathrm{cm}^{-1}\right): 3053,2978,2931,1728,1469$, 1246, 1107. HRMS-ESI $(\mathrm{m} / \mathrm{z})$ calcd for $\mathrm{C}_{28} \mathrm{H}_{30} \mathrm{~N}_{2} \mathrm{O}_{4},[\mathrm{M}+\mathrm{Na}]^{+}$ 481.2104, found 481.2095.

\section{Conflicts of interest}

The authors declare that they have no competing financial interest.

\section{Notes and references}

1 (a) J. M. Finefield, J. C. Frisvad, D. H. Sherman and R. M. Williams, J. Nat. Prod., 2012, 75, 812-833; (b) M. Shiri, Chem. Rev., 2012, 112, 3508-3549; (c) M. Shiri, M. A. Zolfigol, H. G. Kruger and Z. Tanbakouchian, Chem. Rev., 2010, 110, 2250-2293; (d) G. R. Humphrey and J. T. Kuethe, Chem. Rev., 2006, 106, 2875; (e) P. S. Bhadury and J. Pang, Curr. Org. Chem., 2014, 18, 2108-2124.

2 (a) M. Fantacuzzi, B. De Filippis, M. Gallorini, A. Ammazzalorso, L. Giampietro, C. Maccallini, Z. Aturki, E. Donati, R. S. Ibrahim, E. Shawky, A. Cataldi and R. Amoroso, Eur. J. Med. Chem., 2020, 185, 111815; (b) R. I. Al-Wabli, A. A. Almomen, M. S. Almutairi, A. B. Keeton, G. A. Piazza and M. I. Attia, Drug Des. Dev. Ther, 2020, 14, 483-495; (c) M. Demurtas, A. Baldisserotto, I. Lampronti, D. Moi, G. Balboni, S. Pacifico, S. Vertuani,
S. Manfredini and V. Onnis, Bioorg. Chem., 2019, 85, 568576; (d) N. M. Cury, R. M. Capitão, R. do C. B. de Almeida, L. L. Artico, J. R. Corrêa, E. F. Simão dos Santos, J. A. Yunes and C. R. D. Correia, Eur. J. Med. Chem., 2019, 181, 111570; (e) W. Li, H. Sun, F. Xu, W. Shuai, J. Liu, S. Xu, H. Yao, C. Ma, Z. Zhu and J. Xu, Bioorg. Chem., 2019, 85, 49-59; $(f)$ G. La Regina, R. Bai, A. Coluccia, V. Naccarato, V. Famiglini, M. Nalli, D. Masci, A. Verrico, P. Rovella, C. Mazzoccoli, E. Da Pozzo, C. Cavallini, C. Martini, S. Vultaggio, G. Dondio, M. Varasi, C. Mercurio, E. Hamel, P. Lavia and R. Silvestri, Eur. J. Med. Chem., 2018, 152, 283-297.

3 (a) M. F. Khan, T. Anwer, A. Bakht, G. Verma, W. Akhtar, M. M. Alam, M. A. Rizvi, M. Akhter and M. Shaquiquzzaman, Bioorg. Chem., 2019, 87, 667-678; (b) I. D. Vlaicu, R. Olar, C. Maxim, M. C. Chifiriuc, C. Bleotu, N. Stănică, G. Vasile Scăeţeanu, C. Dulea, S. Avram and M. Badea, Appl. Organomet. Chem., 2019, 33, 1-13; (c) G. Verma, G. Chashoo, A. Ali, M. F. Khan, W. Akhtar, I. Ali, M. Akhtar, M. M. Alam and M. Shaquiquzzaman, Bioorg. Chem., 2018, 77, 106-124; (d) S. Fang, L. Chen, M. Yu, B. Cheng, Y. Lin, S. L. Morris-Natschke, K. H. Lee, Q. Gu and J. Xu, Org. Biomol. Chem., 2015, 13, 4714-4726; (e) C. Yu-Jen, M.-S. Shiao, M.-L. Hsu, T.-H. Tsai and W. ShengYuan, J. Agric. Food Chem., 2001, 49, 5615-5619.

4 (a) L. K. Gediya and V. C. Njar, Expert Opin. Drug Discovery, 2009, 4, 1099-1111; (b) C. V. Junior, A. Danuello, V. dS. Bolzani, E. J. Barreiro and C. A. M. Fraga, Curr. Med. Chem., 2007, 14, 1829-1852.

5 A. Arcadi, G. Bianchi, M. Chiarini, G. D'Anniballe and F. Marinelli, Synlett, 2004, 6, 944-950.

6 S. K. Yadav, R. K. Yadav and U. Yadava, DNA Repair, 2020, 86, 102765.

7 (a) R. J. Sundberg, Indoles, Elsevier, 1996; (b) E. C. Taylor, A. H. Katz, H. Salgado-Zamora and A. McKillop, Tetrahedron Lett., 1985, 48, 5963-5966.

8 (a) C. S. Yeung and V. M. Dong, Chem. Rev., 2011, 111, 1215; (b) C. J. Scheuermann, Chem.-Asian J., 2010, 5, 436; (c) C.-J. Li, Acc. Chem. Res., 2009, 42, 335.

9 (a) D. A. Evans, K. R. Fandrick, H. Song, K. A. Scheidt and R. Xu, J. Am. Chem. Soc., 2007, 129, 10029-10041; (b) B. M. Trost and C. Muller, J. Am. Chem. Soc., 2008, 130, 2438-2439; (c) T. Arai and N. Yokoyama, Angew. Chem., Int. Ed., 2008, 47, 4989-4992; (d) R. Rasappan, M. Hager, A. Gissibl and O. Reiser, Org. Lett., 2006, 8, 6099-6102; (e) J. Zhou and Y. Tang, J. Am. Chem. Soc., 2002, 124, 9030-9031. 10 S. Ueno, R. Shimizu and R. Kuwano, Angew. Chem., Int. Ed., 2009, 48, 4543-4545.

11 (a) H. Hikawa and Y. Yokoyama, RSC Adv., 2013, 3, 10611064; (b) M. V. Leskinen, K.-T. Yip, A. Valkonen and P. M. Pihko, J. Am. Chem. Soc., 2012, 134, 5750-5753; (c) Y. Lian and H. M. L. Davies, Org. Lett., 2012, 14, 19341937; (d) K. Aikawa, K. Honda, S. Mimura and K. Mikami, Tetrahedron Lett., 2011, 52, 6682-6686; (e) Y. Cai, S.-F. Zhu, G.-P. Wang and Q.-L. Zhou, Adv. Synth. Catal., 2011, 353, 2939-2949; (f) T. Goto, Y. Natori, K. Takeda, H. Nambu and S. Hashimoto, Tetrahedron: Asymmetry, 2011, 22, 907- 
915; $(g)$ A. N. Campbell, E. B. Meyer and S. S. Stahl, Chem. Commun., 2011, 47, 10257-10259; (h) Q. Liu, G. Li, H. Yi, P. Wu, J. Liu and A. Lei, Chem.-Eur. J., 2011, 17, 23532357; ( $i$ ) H. Liu and D.-M. Du, Eur. J. Org. Chem., 2010, 11, 2121-2131; (j) G. Blay, I. Fernandez, M. C. Munoz, J. R. Pedro and C. Vila, Chem.-Eur. J., 2010, 16, 9117-9121; (k) V. Pirovano, D. Facoetti, M. Dell'Acqua, E. Della Fontana, G. Abbiati and E. Rossi, Org. Lett., 2013, 15, 3812-3815.

12 (a) A. El-Harairy, B. Lai, L. Vaccaro, M. Li and Y. Gu, Adv. Synth. Catal., 2019, 361, 3342-3350; (b) A. El-Harairy, M. Yue, W. Fan, F. Popowycz, Y. Queneau, M. Li and
Y. Gu, ChemCatChem, 2019, 11, 4403-4410; (c) A. El-Harairy and $\mathrm{Y} . \mathrm{Gu}$, ISGC-International Symposium on Green Chemistry, La Rochelle, France, May 2019, https://isgcsymposium-2019.livescience.io/medias/isgc2019/ abstract_submission/_pdf/abstract-892-8B539.pdf.

13 T. Mosmann, J. Immunol. Methods, 1983, 65, 55-63.

14 C. A. Lipinski, Drug Discovery Today: Technol., 2004, 1, 337341.

15 D. F. Veber, S. R. Johnson, H. Y. Cheng, B. R. Smith, K. W. Ward and K. D. Kopple, J. Med. Chem., 2002, 45, 2615-2623.

16 https:/www.molinspiration.com/cgi-bin/properties. 